\title{
Removal of heavy metal ions from drinking water by alginate-immobilised Chlorella sorokiniana
}

\author{
A. Petrovi $\check{c}^{1} \cdot$ M. Simonič ${ }^{1}$
}

Received: 8 December 2015/Revised: 22 March 2016/Accepted: 4 May 2016/Published online: 18 May 2016

(C) Islamic Azad University (IAU) 2016

\begin{abstract}
This paper investigates the potential of alginateimmobilised Chlorella sorokiniana for removing $\mathrm{Cu}^{2+}$, $\mathrm{Ni}^{2+}$ and $\mathrm{Cd}^{2+}$ ions from drinking water solutions. The effects of initial metal concentrations, contact times and temperatures on the biosorptions and removal efficiencies of the tested metals were investigated at initial $\mathrm{pH}$ values of 5, and $\mathrm{pH}$ effects were studied within the range of 3-7. When studying the effects of initial metal concentrations, the highest experimental removal yields achieved for $\mathrm{Cu}^{2+}$, $\mathrm{Ni}^{2+}$ and $\mathrm{Cd}^{2+}$ ions were 97.10, 50.94 and $64.61 \%$, respectively. The maximum biosorption capacities obtained by the Langmuir isotherm model for the biosorptions of $\mathrm{Cu}^{2+}, \mathrm{Ni}^{2+}$ and $\mathrm{Cd}^{2+}$ ions by alginateimmobilised C. sorokiniana were found to be $179.90,86.49$ and $164.50 \mathrm{mg} / \mathrm{g}$ biosorbent, respectively. The experimental data followed pseudo-second-order kinetics. At an initial metal concentration of $25 \mathrm{mg} / \mathrm{L}$, immobilised algae could be used in at least 5 successive biosorption-desorption cycles. SEM and EDS analyses revealed that the metals bonded to the biosorbent. Bi- and multi-metal systems of $\mathrm{Cu}^{2+}, \mathrm{Ni}^{2+}$ and $\mathrm{Cd}^{2+}$ were investigated at initial metal concentrations of 30,50 and $100 \mathrm{mg} / \mathrm{L}$. The removal of $\mathrm{Cd}^{2+}$ as well as $\mathrm{Ni}^{2+}$ in such systems was negatively affected by the presence of $\mathrm{Cu}^{2+}$. The removal efficiency for $\mathrm{Cu}^{2+}$ in multi-metal systems decreased by 5-7\%, whilst in the cases of $\mathrm{Cd}^{2+}$ and $\mathrm{Ni}^{2+}$ the efficiencies decreased by up to $30 \%$. Nevertheless, the results obtained show that alginate-immobilised $C$. sorokiniana can
\end{abstract}

A. Petrovič

ardnaspet@yahoo.com

1 Faculty of Chemistry and Chemical Engineering, University of Maribor, Smetanova 17, 2000 Maribor, Slovenia efficiently remove the metals tested from polluted drinking water sources.

Keywords Algae $\cdot$ Alginate immobilised $\cdot$ Chlorella sorokiniana $\cdot$ Biosorption · Heavy metals · Drinking water

\section{Introduction}

Pollution of the environment and surface water resources by toxic contaminants such as heavy metals has resulted in a number of environmental problems. The presence of these contaminants within the water supply is the consequence of several factors, mainly discharge from metallurgical, textile, plastics, mining, and other industries (Aksu and Dönmez 2006; Kaewsarn and Yu 2001). As a result of their chemical characteristics, toxic effects and accumulation tendencies throughout the food chain, heavy metals represent a serious problem to human health (Mane and Bhosle 2011). They can cause various health problems such as accumulative poisoning, cancer and brain damage when found to be above tolerance levels. Heavy metals such as cadmium, copper and nickel are amongst the more toxic heavy metals responsible for causing these problems. For example, exposure to nickel can lead to dermatitis and allergic sensitisation, whilst exposure to copper can cause stomach and intestinal distress, kidney damage and anaemia (Al-Rub et al. 2004, 2006; Kaewsarn and Yu 2001). Because heavy metals cannot be biodegraded by micro-organisms within the natural environment, the research and development of technologies that can remove these pollutants from water sources is currently a worldwide priority (Gupta et al. 2012a, b; Gupta et al. 2011c; Saleh and Gupta 2011).

A number of physico-chemical methods have been used for the removal of heavy metals from polluted water 
sources, including chemical precipitation, coagulation, solvent extraction, ion exchange, adsorption, and others (Gupta et al. 2013; Gupta and Saleh 2013; Saleh and Gupta 2014). These methods have several disadvantages; they are expensive, harmful to the environment, consume a large amount of energy, and provide incomplete metal removal (Wan Maznah et al. 2012); therefore, using micro-organisms as biosorbents for heavy metals offers a potential alternative to existing methods for removing these compounds from water. Biosorption is the process of adsorption by either living microbial biomass or dead microbial biomass. The advantages of biosorption, which is based on ionic interactions and complex formations between metal ions and the functional groups of the biosorbent, are low operating cost, selectivities for specific metals, relatively high efficiencies, and minimisation of the volumes of chemical and biological sludge (Flouty and Estephane 2012; Mane and Bhosle 2011).

Several live micro-organisms (algae, bacteria, fungi and yeast) have been investigated for metal adsorption from polluted waters, and algae especially have proven to be very useful for this purpose because of their availability, low costs and ability to uptake large quantities of heavy metals (Monteiro et al. 2011). Compared to fungi and yeast, algae have been proved to have higher heavy metal biosorption capacities because of their cell walls, which are composed of a fibre-like structure and an amorphous embedding matrix of various polysaccharides (Akhtar et al. 2008). Moreover, heavy metal removal by algal biomass is comparable to or sometimes even higher than that of chemical sorbents (Wan Maznah et al. 2012).

Different natural immobilisation media, such as alginates, carrageenan, chitosan, chitin and cellulose derivatives, have been used for algal cell immobilisation nevertheless, and alginate is still one of the more frequently used carriers because of its advantages such as very simple preparation, biocompatibility and cost-effective immobilisation (Akhtar et al. 2003). Cell immobilisation may enhance biosorption capacity and offer opportunity for biomass retention within the working environment because of its easy separation of products from cells and relatively high local cell density (Al-Rub et al. 2004; Kumar and Das 2012). The diameter and biomass concentration of algal beads may also influence the metal removal efficiency of biomass (Mehta and Gaur 2001). In addition, other environmental parameters such as $\mathrm{pH}$ and temperature, contact time, and initial metal concentration play significant roles within this process (Sar1 and Tuzen 2009).

A number of microalgal species such as Chlorella vulgaris (Aksu 2002; Rodrigues et al. 2012), Scenedesmus sp.(Chong et al. 2000; Monteiro et al. 2011), Chlamydomonas sp. (Flouty and Khalaf 2015), Spirullina sp. (Mane and Bhosle 2011) and Chlorella sorokiniana
(Akhtar et al. 2004; Carfagna et al. 2013; Chong et al. 2000; Yoshida et al. 2006) has been used during biosorption studies on heavy metals and showed varying removal efficiencies.

Despite $C$. sorokiniana being reported as an adequate algae species for biosorption of heavy metals, only a few studies about this species have been available to date. Yoshida et al. (2006) reported that cells of $C$. sorokiniana isolated from soil were highly resistant to heavy metals and were capable of taking up heavy metal ions such as $\mathrm{Cd}^{2+}, \mathrm{Zn}^{2+}$ and $\mathrm{Cu}^{2+}$. During another study, a series of batch experiments was conducted comparing the abilities of 11 microalgal species, including $C$. sorokiniana, in removing nickel and zinc from synthetic wastewater (Chong et al. 2000). Physiological and morphological responses of lead or cadmium-exposed $C$. sorokiniana were studied by Carfagna et al. (2013). Loofa sponge immobilised biomass of $C$. sorokiniana, isolated from industrial wastewater, was investigated as a biosorbent for the removal of chromium and nickel from aqueous solutions. The effects of environmental factors on metal uptake capacity were studied and compared with free biomass of $C$. sorokiniana (Akhtar et al. 2004, 2008). The potential of microalgal cells immobilised in the biostructural matrix of Luffa cylindrica for sequestering cadmium was also examined in one study (Akhtar et al. 2003).

Whilst the uptake of metals from solutions containing single-metal ions by algae as a biosorbent has been extensively studied to date, less attention has been paid to the biosorption of multi-metal systems by complex uptake mechanisms. The competitive biosorption of $\mathrm{Cd}^{2+}$ and $\mathrm{Ni}^{2+}$ metal ions by dried Chlorella vulgaris from binary metal mixtures was studied and compared to the single-metal ion situation within a batch-stirred system by Aksu and Dönmez (2006). In another study, a comparative evaluation of bioaccumulation and biosorption of $\mathrm{Cu}^{2+}$ and $\mathrm{Pb}^{2+}$ ions by algal cells of Chlamydomonas reinhardtii was conducted within binary metal systems (Flouty and Estephane 2012). Binary and ternary systems of $\mathrm{Ni}^{2+}, \mathrm{Zn}^{2+}$ and $\mathrm{Pb}^{2+}$ were also investigated at different initial metal concentrations with competitive adsorbates using Arthrospira platensis and Chlorella vulgaris as biosorbents (Rodrigues et al. 2012). However, biosorption studies on C. sorokiniana free cells have been performed only on single and bi-metal systems according to these papers, and there has been no study on multi-metal systems. Moreover, none of the investigations examined heavy metal biosorption by $C$. sorokiniana algal cells entrapped in Ca-alginate, and no investigations have been performed on drinking water sources.

Since immobilisation technology could protect algal cells and enhance their biosorption capacity, the aim of this study was to explore the feasibility of alginate-immobilised Chlorella sorokiniana for removing $\mathrm{Cu}^{2+}, \mathrm{Cd}^{2+}$ and $\mathrm{Ni}^{2+}$ ions from drinking water samples. Because these heavy 
metals are widely used in industry and thus often appear in sources of drinking water, they were chosen for biosorption studies with $C$. sorokiniana under various experimental conditions such as different initial metal concentrations, $\mathrm{pH}$, temperature and contact time. Langmuir, Freundlich, Dubinin-Raduskhevich and Redlich-Peterson isotherm models were applied in order to describe the equilibrium data obtained. For the first time, multi-metal systems of $\mathrm{Cu}^{2+}, \mathrm{Ni}^{2+}$ and $\mathrm{Cd}^{2+}$ ions were investigated with this algae species, the interactions between tested metals were studied, and their impacts on biosorption efficiencies and capacities were evaluated. This study therefore presents an important contribution to the research and better understanding of metal uptake by this algae species. The research was implemented between 2012 and 2015 at the Faculty of Chemistry and Chemical Engineering at the University of Maribor, Slovenia.

\section{Materials and methods}

\section{Algal culture and immobilisation of cells}

Biosorption experiments on drinking water were performed using the freshwater algae species Chlorella sorokiniana. As C. sorokiniana is capable of growth under different growth conditions (Kim et al. 2013; Lizzul et al. 2014), is able to remove various heavy metals from water (Akhtar et al. 2004, 2008; de-Bashan and Bashan 2010) and can tolerate highly polluted environments and extreme conditions (i.e. temperature and light) (de-Bashan et al. 2008; Riaño et al. 2012), it was an appropriate choice for the present study. Cells of Chlorella sorokiniana were delivered from the local algal technology centre (AlgEn, Slovenia) and cultivated in Bold's Basal growth media under room conditions (Bischoff and Bold 2003). After 10 days of cultivation when the microalgae were acclimatised, the algal cells were harvested by centrifugation (at $3500 \mathrm{rpm}$ for $10 \mathrm{~min}$ ).

The harvested algal cells were immobilised in sodium alginate, which offers various benefits: in the case of its application to drinking water treatment, the most important thing is that it is non-toxic and it allows simple, fast and costeffective immobilisation. Immobilised algal beads were prepared using the procedure described in one of our previous studies, whereby algae-alginate gel suspension (2\% alginate) was dropped into $2 \% \mathrm{CaCl}_{2}$ solution (Petrovič and Simonič 2015). Prepared beads with diameters in the range of $3.5 \pm 0.5 \mathrm{~mm}$ (with cell numbers of around $4.5 \times 10^{5}$ cells bead ${ }^{-1}$ ) were transferred to the algal growth medium and incubated under room conditions for 3-4 days. After a short incubation, the beads with immobilised algal cells were removed from the medium and washed twice with saline solution $(0.85 \%)$ and finally with distilled water.

\section{Analytical procedures}

Several analyses were carried out throughout the experiment. The samples were filtered through GF-3 filters (Macherey-Nagel) in order to exclude most of the solids present in the water and diluted before analysis if necessary.

The metal contents within the solutions (residual concentrations of copper, nickel and cadmium) were determined by an atomic absorption spectrophotometer (Perkin-Elmer, AAnalyst 400). The calculations for all three metals were made according to a previously prepared calibration curve. The metal concentration removed by immobilised algal beads was determined by subtracting the residual metal concentration from the initial metal concentration within the solution. The $\mathrm{pH}$ and temperature were measured by a WTW InoLab Multi 720 measuring instrument (the instrument's accuracy for $\mathrm{pH}$ measurements was \pm 0.01 ). The number of algal cells in the beads was counted using a Neubauer haemocytometer after dissolving the alginate beads in $10 \mathrm{~mL}$ of $0.1 \mathrm{M}$ trisodium citrate solution (Mehta and Gaur 2001).

\section{Characterisation studies}

The water content of the algal beads was determined after drying a weighed sample in a vacuum oven at $60{ }^{\circ} \mathrm{C}$ until constant weight was achieved (for approx. 48 h). Finally, from the difference between the weights of the wet and dry samples, the water content was calculated.

The specific surface area, the pore sizes and the pore volume of the $C$. sorokiniana immobilised alginate beads were measured using a Micromeritics ASAP 2020MP surface area apparatus according to the following procedure. After obtaining hydrogel spheres, the alcogels were formed by solvent exchange using $100 \%$ ethanol. The hydrogel spheres were dehydrated by immersion within a series of successive ethanol-water baths of increasing ethanol concentrations (10, $30,50,70,90$ and $100 \%$ ). Ethanol was then removed from the alcogels (algal beads) by supercritical drying with carbon dioxide at $40{ }^{\circ} \mathrm{C}$ and 100 bar for $6-7 \mathrm{~h}$. Gas adsorption measurements were applied for defining the surface area and pore-size distributions of the material in a Micromeritics ASAP 2020MP at $-196{ }^{\circ} \mathrm{C}$ after degassing the sample at $70{ }^{\circ} \mathrm{C}$ for $660 \mathrm{~min}$ under vacuum, until a stable $10 \mu \mathrm{m} \mathrm{Hg}$ pressure was obtained. The BET (Brunauer, Emmett and Teller) equation was used for determining the surface area by assuming a $0.162 \mathrm{~nm}^{2} /$ molecule as the molecular area of $\mathrm{N}_{2}$.

Scanning electron microscopy (SEM) combined with energy dispersive X-ray spectroscopy (EDS) analysis was used to identify the effects of metal sorption on the surface morphologies of the algal beads. The algal beads were first exposed to certain metal ion concentrations $(30 \mathrm{mg} / \mathrm{L}$ of each metal, exposure time $180 \mathrm{~min}$ ) and then dried with tissue paper in order to remove the excess surface water. 
The specimens were attached to a stainless steel carrier and coated with a thin layer of gold under vacuum to increase the electrical conductivity of each sample and to protect the sample's structure from electron beam damage and dehydration within a vacuum. The specimens were observed using a Quanto 2003D FEI scanning electron microscope, equipped with a Sirion 400 FEI energy dispersive microanalysis system (Oxford Instruments, UK) at $15 \mathrm{kV}$.

The Fourier transform infrared (FTIR) spectra of the immobilised alginate beads exposed to metals (at initial metal concentrations of each metal $30 \mathrm{mg} / \mathrm{L}$, exposure time $180 \mathrm{~min}$ ) and those non-exposed to metals were obtained using an FTIR spectrophotometer (FTIR Shimadzu IRAffinity -1 , Japan). The samples were then dried within a vacuum oven at $60{ }^{\circ} \mathrm{C}$ until constant weight. The dry sample of immobilised algae was afterwards gently mixed with $\mathrm{KBr}$ powder (at a ratio of 1:30) and pressed into tablet form at a force of $98 \mathrm{kN}$ for 6 min using a manual tablet presser. Finally, the FTIR spectra were recorded at room temperature in the range of $400-4000 \mathrm{~cm}^{-1}$.

\section{Biosorption studies}

\section{Single-metal systems}

Stock solutions of $\mathrm{Cu}^{2+}, \mathrm{Cd}^{2+}$ or $\mathrm{Ni}^{2+}$ ions (with concentration of $1 \mathrm{~g} / \mathrm{L}$ ) were obtained by dissolving exact amounts of high-purity $\mathrm{CuSO}_{4}$ (Merck), $3 \mathrm{CdSO}_{4} \times 8 \mathrm{H}_{2} \mathrm{O}$ (Merck) and $\mathrm{Ni}\left(\mathrm{NO}_{3}\right)_{2} \times 6 \mathrm{H}_{2} \mathrm{O}$ (Merck), in $1 \mathrm{~L}$ of distilled water, respectively. The working solutions of $250 \mathrm{~mL}$ were obtained by diluting the appropriate amount of each stock solution with the drinking water sample, in which initial metal concentrations varied between 5 and $320 \mathrm{mg} / \mathrm{L}$. The biosorption experiments were performed in $300-\mathrm{mL}$ Erlenmeyer flasks with $250 \mathrm{~mL}$ of working solutions stirred by a magnetic stirrer at $150 \mathrm{rpm}$. All tests, except when studying the impact of temperature, were conducted at room temperature $(23 \pm 1.2)$. The biosorption tests were carried out with $15 \pm 1.5 \mathrm{~g}$ of wet algal beads. Otherwise, in the calculations, the dry weight of biosorbent was used ( $\sim 0.3 \mathrm{~g})$ since water content was taken into account. The error bars given for the temperature and biosorbent weight represent the standard deviation of the measurements.

The samples for the analysis of metal content were withdrawn at the beginning of the biosorption (zero time) and then at different time intervals, until the equilibrium state was established in the solution. Before being used in the analysis, the samples were filtered through glass fibre filters marked as GF-3. The metal content within the solutions was then analysed by an atomic absorption spectrophotometer.

The effect of contact time on the biosorption of $\mathrm{Cu}^{2+}$, $\mathrm{Cd}^{2+}$ or $\mathrm{Ni}^{2+}$ ions by alginate-immobilised C. sorokiniana was studied at an initial metal concentration of $50 \mathrm{mg} / \mathrm{L}$ $(\mathrm{pH}=5)$, and the contact time increased from 0 min up to $300 \mathrm{~min}$. All other experiments were performed with contact times of $180 \mathrm{~min}$.

The impact of $\mathrm{pH}$ was examined at an initial metal concentration of $25 \mathrm{mg} / \mathrm{L}$ at $\mathrm{pH}$ varying from 3 to 7 . The $\mathrm{pH}$ of each test solution was adjusted to the required value with dilute $\mathrm{H}_{2} \mathrm{SO}_{4}$ and $\mathrm{NaOH}$ solutions.

In order to study the effect of temperature, biosorption studies were carried out for each heavy metal at three different temperatures, 20, 30 and $40{ }^{\circ} \mathrm{C}$, at an initial metal concentration of $25 \mathrm{mg} / \mathrm{L}$ and $\mathrm{pH}$ values of 5 (at contact time of $180 \mathrm{~min}$ ). The temperature of the solutions was controlled by using a water bath.

The impact of the initial metal concentration on biosorption by alginate-immobilised $C$. sorokiniana was studied within the range of $5-320 \mathrm{mg} / \mathrm{L}$ for $\mathrm{Cu}^{2+}$ ions, for the $\mathrm{Ni}^{2+}$ ions between $8-200 \mathrm{mg} / \mathrm{L}$ and for the $\mathrm{Cd}^{2+}$ ions within the range of $10-280 \mathrm{mg} / \mathrm{L}$. These experiments were performed at the same $\mathrm{pH}$ value and temperature as those experiments in which the influence of contact time was studied, except the contact time was lower (180 min).

In order to study the impact of repeated biosorption cycles on biosorption efficiency, several biosorption-desorption cycles were performed under the same conditions. The biosorptions were conducted at $\mathrm{pH} 5$, initial metal concentration of $25 \mathrm{mg} / \mathrm{L}$ and at contact time of $180 \mathrm{~min}$. The desorption of each metal was performed by using appropriate amounts of $0.02 \mathrm{M}$ EDTA solution contacted with biosorbent at room temperature and stirred at $150 \mathrm{rpm}$ for $1.5 \mathrm{~h}$. The algal beads were then washed with deionised water and regenerated with $2 \% \mathrm{CaCl}_{2}$ solution (1-2 h) to strengthen the beads. Before being used in the next biosorption cycle, the algal beads were again washed with deionised water, then with $0.85 \% \mathrm{NaCl}$, and finally with deionised water.

\section{Bi-metal and multi-metal systems}

The biosorption experiments on bi-metal and multi-metal systems were performed in an Erlenmeyer flask using $250 \mathrm{~mL}$ of drinking water solution containing known concentrations of each metal $\left(\mathrm{Cu}^{2+}, \mathrm{Ni}^{2+}\right.$ and $\left.\mathrm{Cd}^{2+}\right)$ at room temperature and $\mathrm{pH} 5$. The concentrations of prepared stock solutions were the same as in the case of single-metal systems $(1 \mathrm{~g} / \mathrm{L})$. The biosorption tests were carried out with the same amount of biosorbent as used in those experiments on single-metal systems. In order to ensure equilibrium conditions, the solutions were mixed by a magnetic stirrer $(150 \mathrm{rpm})$ for $180 \mathrm{~min}$. The concentration of metals in the filtered samples was measured at similar time intervals as for the single-metal solutions (from 0 up to $180 \mathrm{~min}$ ). 
Biosorption experiments on bi-metal systems were conducted with solutions in which the initial concentration of a chosen metal was held constant at $30 \mathrm{mg} / \mathrm{L}$, whilst the initial concentration of other, i.e. competing metal ion was varied $(30,50$ or $100 \mathrm{mg} / \mathrm{L})$. In addition, the biosorption experiments were also conducted wherein the initial concentrations of both metals present in the solution were the same (at initial concentrations of 30, 50 and $100 \mathrm{mg} / \mathrm{L}$ ). The biosorption experiments on multimetal systems were performed in the same way as those experiments on bi-metal systems and at the same initial metal concentrations $(30,50$ and $100 \mathrm{mg} / \mathrm{L})$, except that in this case the solutions contained all three metals at once. The initial concentration of one of the metals was varied, whilst the initial concentrations of other two metals were constant.

\section{Biosorption capacity, isotherm and kinetics models}

The sorption capacity of biosorption by the alginate-immobilised $C$. sorokiniana was obtained using the following equation (Eq. 1) (Al-Rub et al. 2006):

$q=\frac{\left(c_{0}-c_{\mathrm{e}}\right) V}{m}$

where $q$ is the sorption capacity (the amount of metal adsorbed onto the unit amount of biosorbent) in $\mathrm{mg} / \mathrm{g}, c_{0}$ and $c_{\mathrm{e}}$ are the initial metal concentration and concentration at equilibrium (both in $\mathrm{mg} / \mathrm{L}$ ), $V$ is the volume of solution (L) and $m$ is the amount of biosorbent $(\mathrm{g})$.

The Langmuir, Freundlich, Dubinin-Radushkevich and Redlich-Peterson sorption isotherm models (Blanes et al. 2011; Dubinin 1960; Foo and Hameed 2010; Freundlich 1926; Langmuir 1916) were used for modelling equilibrium data obtained from the biosorptions of $\mathrm{Cu}^{2+}, \mathrm{Ni}^{2+}$ and $\mathrm{Cd}^{2+}$ ions (Table 1; Eqs. 5-8).

The Freundlich isotherm model (Eq. 6) is the earliest known relationship describing non-ideal and reversible adsorption. This empirical model can be applied to multilayer adsorption, with non-uniform distribution of adsorption heat and affinities over the heterogeneous surface (Foo and Hameed 2010; Freundlich 1926). If the value of $1 / n$ is less than one (see Table 1, Eq. 6), it indicates a normal adsorption, when $1 / n>1$ then it indicates cooperative adsorption and when $1>n<10$ it indicates a favourable sorption process (Saleh 2015a).

The Langmuir isotherm model (Eq. 5) assumes monolayer adsorption (the adsorbed layer is one molecule in thickness) taking place at a finite number of binding sites that are identical and equivalent, with no lateral interactions between the adsorbed molecules, nor is there transmigration on the surface of adsorbent (Foo and Hameed 2010; Langmuir 1916). The Langmuir parameter $b$ can be used to express the affinity between the sorbate and sorbent using the dimensionless separation factor $R_{\mathrm{L}}$, which indicates the isotherm shape that predicts whether an adsorption system is favourable or unfavourable. The dimensionless separation factor $R_{\mathrm{L}}$ is determined according to Eq. 2 (Al-Rub et al. 2004; Hall et al. 1966):

$R_{\mathrm{L}}=1 /\left(1+b c_{0}\right)$

An $R_{\mathrm{L}}$ value less than 1 indicates favourable adsorption. The dimensionless separation factor for each of the metals was calculated at initial metal concentration of $c_{0}=50 \mathrm{mg} / \mathrm{L}$.

The Redlich-Peterson triple parameter equation (Eq. 8) incorporates the features of the Langmuir and Freundlich isotherms into a single equation. Thus, this model is capable of representing adsorption equilibrium over a wide concentration range and can be applied either in homogeneous or heterogeneous systems because of its flexibility (Blanes et al. 2011; Foo and Hameed 2010).

The Dubinin-Radushkevich isotherm model (Eq. 7) assumes that adsorption has a multilayer character, involves van der Waals forces and is applicable to physical adsorption processes (Abdel-Ghani and El-Chaghaby 2014). Therefore, it is generally applied to express the adsorption mechanism with a Gaussian energy distribution onto a heterogeneous surface. By using the DubininRadushkevich constant $K_{\mathrm{DR}}$, the mean free energy of biosorption $E[\mathrm{~kJ} / \mathrm{mol}]$ was calculated (see Eq. 3), giving information about the biosorption mechanism, i.e. type of biosorption (Aksu 2002; Blanes et al. 2011; Sar1 and Tuzen 2009):

$E=\left(2 K_{\mathrm{DR}}\right)^{-1 / 2}$

The models' constants were determined by fitting the equilibrium data of each of the metals (least squares fitting) to respective equations using MATLAB software. The equilibrium data for the biosorption of metal ions were obtained from the biosorption experiments at various initial

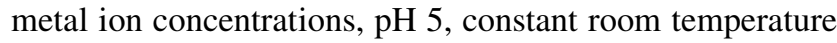
$23 \pm 1.2^{\circ} \mathrm{C}$ and contact time $180 \mathrm{~min}$.

In order to study the biosorption kinetics of $\mathrm{Cu}^{2+}, \mathrm{Ni}^{2+}$ and $\mathrm{Cd}^{2+}$ ions, pseudo-first-order and pseudo-second-order kinetic models (Table 1, Eqs. 9 and 10) were applied to the sorption data (Ho and McKay 1998, 1999; Lagergren 1898). The parameters of the pseudo-second-order kinetic model $\left(q_{\mathrm{e}}\right.$ and $\left.k_{2}\right)$ were determined from the slope and the intercept of the linear plots $t / q_{\mathrm{t}}$ versus $t$, whilst for the pseudo-first-order model the linear plots of $\log \left(q_{\mathrm{e}}-q_{\mathrm{t}}\right)$ against $t$ were applied. The kinetic parameters of pseudofirst model ( $k_{1}$ and $q_{\mathrm{e}}$ ) were obtained in the same way as before. These calculations were obtained from the data achieved in biosorption of $\mathrm{Cu}^{2+}, \mathrm{Ni}^{2+}$ and $\mathrm{Cd}^{2+}$ ions at initial metal concentration of $50 \mathrm{mg} / \mathrm{L}(\mathrm{pH}=5$, contact 
time $180 \mathrm{~min}$, room temperature). Finally, the model with the highest correlation coefficient value $\left(R^{2}\right)$ was considered to be the most appropriate model to describe the obtained data.

The separation factors $\alpha_{2}^{1}$ for bi-metal systems were calculated by using Eq. 4 :

$\alpha_{2}^{1}=\frac{q_{\mathrm{e}, 1} c_{\mathrm{e}, 2}}{q_{\mathrm{e}, 2} c_{\mathrm{e}, 1}}$

if $\alpha_{2}^{1}>1$, then metal 1 is preferred, and when $\alpha_{2}^{1}<1$, metal 2 is preferred (Rodrigues et al. 2012). The separation factors $\alpha_{2}^{1}$ of chosen bi-metal systems were calculated for the experiments conducted at initial metal concentrations of 30,50 and $100 \mathrm{mg} / \mathrm{L}$ and also at different combinations of these concentrations.

\section{Results and discussion}

\section{Single-metal biosorption}

\section{Effect of contact time for single-metal systems}

The effect of contact time on the biosorption of $\mathrm{Cu}^{2+}, \mathrm{Ni}^{2+}$ and $\mathrm{Cd}^{2+}$ ions by alginate-immobilised $C$. sorokiniana is shown in Fig. 1. The experiments were performed at initial metal concentrations of $50 \mathrm{mg} / \mathrm{L}$, biosorbent amount of $0.3 \mathrm{~g}$ and $\mathrm{pH} 5$.

The sorption capacities of metals by alginate-immobilised algae increased up to $37.85,19.34$ and $29.08 \mathrm{mg} / \mathrm{g}$ for $\mathrm{Cu}^{2+}$, $\mathrm{Ni}^{2+}$ and $\mathrm{Cd}^{2+}$ ions as the contact time increased from $0 \mathrm{~min}$ to 300 min. The efficiencies for $\mathrm{Cu}^{2+}, \mathrm{Ni}^{2+}$ and $\mathrm{Cd}^{2+}$ ions

Table 1 The isotherm and kinetics models used in modelling the sorption data (Blanes et al. 2011; Dubinin 1960; Foo and Hameed 2010; Freundlich 1926; Ho and McKay 1998, 1999; Lagergren 1898; Langmuir 1916)

\begin{tabular}{|c|c|c|c|}
\hline Model & Equation & Eq. no. & Constants/parameters \\
\hline Langmuir & $q_{\mathrm{e}}=\frac{q_{\mathrm{m}} b c_{\mathrm{e}}}{1+b c_{\mathrm{e}}}$ & (5) & $\begin{array}{l}q_{\mathrm{e}} \text { - biosorption capacity at equilibrium }[\mathrm{mg} / \mathrm{g}] \\
q_{\mathrm{m}} \text {-maximum theoretical biosorption capacity of sorbent under the given } \\
\text { conditions }[\mathrm{mg} / \mathrm{g}] \\
b \text { - equilibrium biosorption constant related to the affinity between the sorbent } \\
\text { and sorbate }[\mathrm{L} / \mathrm{mg}] \\
c_{\mathrm{e}} \text { - equilibrium concentration of metal }[\mathrm{mg} / \mathrm{L}]\end{array}$ \\
\hline Freundlich & $q_{\mathrm{e}}=K_{\mathrm{F}} c_{\mathrm{e}}^{1 / n}$ & (6) & $\begin{array}{l}q_{\mathrm{e}} \text { - biosorption capacity at equilibrium }[\mathrm{mg} / \mathrm{g}] \\
K_{\mathrm{F}}-\text { Freundlich isotherm biosorption constant for relative biosorption capacity } \\
{\left[(\mathrm{mg} / \mathrm{g})(\mathrm{mg} / \mathrm{L})^{\mathrm{n}}\right]} \\
n \text {-Freundlich model exponent related to the biosorption intensity (i.e. } \\
\text { heterogeneity factor) } \\
c_{\mathrm{e}} \text {-equilibrium concentration of metal }[\mathrm{mg} / \mathrm{L}]\end{array}$ \\
\hline $\begin{array}{l}\text { Dubinin- } \\
\text { Radushkevich }\end{array}$ & $q_{\mathrm{e}}=\left(q_{\mathrm{m}}\right) \exp \left(-K_{\mathrm{DR}} \varepsilon^{2}\right)$ & (7) & $\begin{array}{l}q_{\mathrm{e}} \text {-biosorption capacity at equilibrium }[\mathrm{mg} / \mathrm{g}] \\
K_{\mathrm{DR}}-\text { Dubinin-Radushkevich constant, inversely related to the mean free energy } \\
\text { of biosorption }\left[\mathrm{mol}^{2} / \mathrm{kJ}^{2}\right] \\
q_{\mathrm{m}} \text { - maximum theoretical biosorption capacity }[\mathrm{mg} / \mathrm{g}] \\
\varepsilon \text {-Polanyi potential }\left(\varepsilon=R T \ln \left(1+1 / c_{\mathrm{e}}\right)\right) \\
c_{\mathrm{e}} \text { - equilibrium concentration of metal }[\mathrm{mg} / \mathrm{L}] \\
R \text { - gas constant }\left[8.314 \times 10^{-3} \mathrm{~kJ} / \mathrm{mol}^{*} \mathrm{~K}\right] \\
T \text { - absolute temperature }[\mathrm{K}]\end{array}$ \\
\hline Redlich-Peterson & $q_{\mathrm{e}}=\frac{K_{\mathrm{RP}} c_{\mathrm{e}}}{1+a_{\mathrm{RP}} c_{\mathrm{e}}^{n}}$ & (8) & $\begin{array}{l}q_{\mathrm{e}} \text { - biosorption capacity at equilibrium }[\mathrm{mg} / \mathrm{g}] \\
K_{\mathrm{RP}}-\text { Redlich-Peterson isotherm constant }[\mathrm{L} / \mathrm{g}] \\
a_{\mathrm{RP}}-\text { Redlich-Peterson isotherm model constant }[\mathrm{L} / \mathrm{mg}] \\
n \text {-Redlich-Peterson isotherm model exponent } \\
c_{\mathrm{e}} \text { - equilibrium concentration of metal }[\mathrm{mg} / \mathrm{L}]\end{array}$ \\
\hline $\begin{array}{l}\text { Pseudo-first } \\
\text { order }\end{array}$ & $\log \left(q_{\mathrm{e}}-q_{\mathrm{t}}\right)=\log q_{\mathrm{e}}-\left(\frac{k_{1}}{2.303}\right) t$ & (9) & $\begin{array}{l}q_{\mathrm{e}} \text {-biosorption capacity at equilibrium }[\mathrm{mg} / \mathrm{g}] \\
k_{1} \text {-the rate constant of pseudo-first order biosorption }\left[\mathrm{min}^{-1}\right] \\
q_{\mathrm{t}} \text { - biosorption capacity at time } t[\mathrm{mg} / \mathrm{g}]\end{array}$ \\
\hline $\begin{array}{l}\text { Pseudo-second } \\
\text { order }\end{array}$ & $\frac{t}{q_{\mathrm{t}}}=\frac{t}{q_{\mathrm{e}}}+\frac{1}{k_{2} q_{\mathrm{e}}^{2}}$ & (10) & $\begin{array}{l}q_{\mathrm{e}} \text {-biosorption capacity at equilibrium }[\mathrm{mg} / \mathrm{g}] \\
k_{2} \text {-the rate constant of pseudo-second-order biosorption }[\mathrm{g} /(\mathrm{mg} * \mathrm{~min})] \\
q_{\mathrm{t}} \text {-biosorption capacity at time } t[\mathrm{mg} / \mathrm{g}]\end{array}$ \\
\hline
\end{tabular}




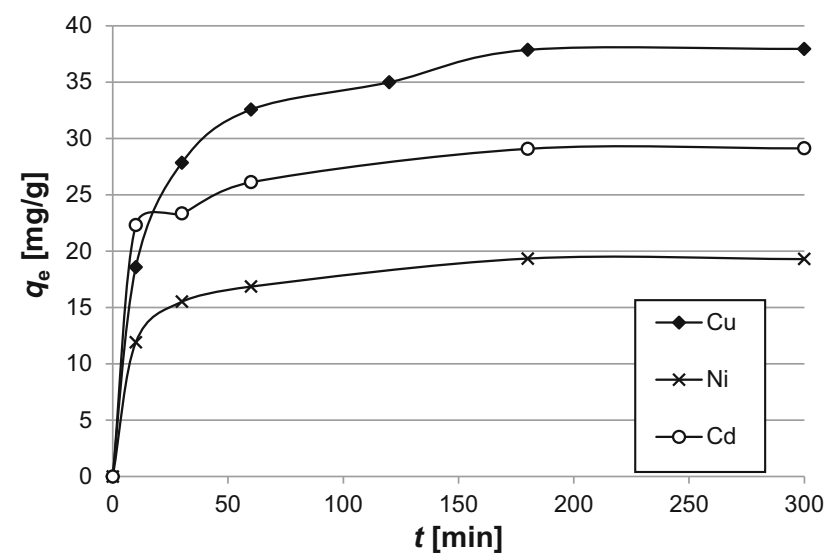

Fig. 1 Removal of $\mathrm{Cu}^{2+}, \mathrm{Ni}^{2+}$ and $\mathrm{Cd}^{2+}$ ions from drinking water by alginate-immobilised $C$. sorokiniana as a function of contact time (initial metal concentration of $50 \mathrm{mg} / \mathrm{L}, \mathrm{pH}$ )

achieved under these experimental conditions were 84.16, 41.58 and $64.61 \%$, respectively. For all three tested metals, the experimental data indicated that the amounts of each heavy metal biosorbed increased rapidly with the contact time up to $25 \mathrm{~min}$, and after that the biosorption rate became slower. The highest values were obtained between 180 and $300 \mathrm{~min}$. After $180 \mathrm{~min}$, no noticeable increase in metal removal by algal beads was observed, indicating that equilibrium conditions had been achieved. Thus, $180 \mathrm{~min}$ is considered to be adequate for the biosorption of metals by alginate-immobilised $C$. sorokiniana. Similar contact times have been used in other investigations (Aksu 2001; Bulgariu and Bulgariu 2012; Chong et al. 2000; Romera et al. 2007).

The mechanism of heavy metal biosorption process can be described as follows: firstly, the metal ions are transferred from the solution to the biosorbent surface, which contain various functional groups that act as active binding sites, and depending on $\mathrm{pH}$, cationic or anionic sites are available for biosorption, wherein physical sorption, chemosorption, or ion-exchange occurs rapidly. The functional groups that have previously been reported to be effective at attracting heavy metal ions are mainly carboxyl, hydroxyl, sulphate, phosphate, amino, amido and phenolic groups (Romera et al. 2007; Wan Maznah et al. 2012). The first step is mostly affected by metal ion concentration, agitation period and rate (Bayramoğlu and Yakup Arıca 2009). The second step includes transport, i.e. diffusion of metal ions into pores of adsorbent, whilst the last stage is related to the diffusion of the metal ions on the internal surface of the material and is considered to be a rate-limiting step (Flouty and Estephane 2012; Mane and Bhosle 2011).

\section{Effect of $\mathrm{pH}$ and temperature for single-metal systems}

The $\mathrm{pH}$ of the aqueous solution is considered to be one of the most important factors for heavy metal biosorption, since $\mathrm{pH}$ affects the charge on the surface of the biosorbents and the metal chemistry in water and thus the solubility of metal ions (Bulgariu and Bulgariu 2012; Kaewsarn and $\mathrm{Yu}$ 2001; Romera et al. 2007). The impacts of initial $\mathrm{pH}$ on the biosorption capacities of $\mathrm{Cu}^{2+}, \mathrm{Cd}^{2+}$ and $\mathrm{Ni}^{2+}$ ions by alginate-immobilised $C$. sorokiniana are shown in Fig. 2a. The pH effects were studied within a range of 3-7 at initial metal concentrations of $25 \mathrm{mg} / \mathrm{L}$. As Fig. 2a shows, the removal capacities for copper increase with $\mathrm{pH}$ up to 5 but at $\mathrm{pH}$ values around 5.5 or higher, a precipitation effect was observed; therefore, in this case the $\mathrm{pH}$ effect was not studied at $\mathrm{pH}$ 7. The problem of copper precipitation at $\mathrm{pH}$ higher than 5.5 has been noticed in an earlier biosorption study on $C$. vulgaris (Al-Rub et al. 2006). Otherwise, the maximum capacity (efficiency) for $\mathrm{Cu}^{2+}$ ions was calculated to be $20.24 \mathrm{mg} / \mathrm{g}(98.86 \%)$. This is in agreement with previous investigations which showed increased metal sorption with increasing $\mathrm{pH}$ of the solution (Wan Maznah et al. 2012). Thus, the increase in the initial solution $\mathrm{pH}$ will result in an increase in the dissociation degrees of functional groups from the biosorbent surfaces, and as a consequence, the number of electrostatic interactions will increase (Bulgariu and Bulgariu 2012). Another aspect that should be considered in the biosorption of metals is metal speciation in solution, since metals in water solutions may occur in different metal ion species depending on the solution $\mathrm{pH}$ (Abdel-Ghani and El-Chaghaby 2014; Gupta et al. 2011a, b; Saleh et al. 2011). For instance, $\mathrm{Cu}$ (II) appears in water solutions as $\mathrm{Cu}^{2+}$ at $\mathrm{pH}$ values up to 5 , whilst at $\mathrm{pH} 4-5$ other $\mathrm{Cu}$ (II) species like $\mathrm{Cu}(\mathrm{OH})^{+}$are present, and $\mathrm{Cu}(\mathrm{OH})_{2}$ can be found at pH $>6$ (Abdel-Ghani and El-Chaghaby 2014). A decrease in adsorption could therefore be observed after a certain $\mathrm{pH}$ owing to the hydrolysis of metal ions as well as the increased concentration of hydroxyl ions or anionic species in the medium.

In the case of $\mathrm{Cd}^{2+}$ biosorption, the highest capacity for $\mathrm{Cd}^{2+}$ ions, $19.22 \mathrm{mg} / \mathrm{g}$, in this study was measured at $\mathrm{pH} 4$, and then with increasing $\mathrm{pH}$, the values decreased. However, the strongest $\mathrm{pH}$ effect on biosorption capacities was observed in the biosorption of $\mathrm{Cd}^{2+}$ ions, whilst in the case of $\mathrm{Ni}^{2+}$ biosorption the capacities were less obviously affected. The forms of $\mathrm{Cd}(\mathrm{II})$ species that are mainly present in water solutions are $\mathrm{Cd}^{2+}, \mathrm{Cd}(\mathrm{OH})_{2}$ and $\mathrm{Cd}(\mathrm{OH})^{+}$. $\mathrm{Cd}^{2+}$ is the predominant species at low $\mathrm{pH}$ range (3.5-5), but at higher $\mathrm{pH}$ values $(\mathrm{pH}>7) \mathrm{Cd}(\mathrm{II})$ ions have a tendency to precipitate $\mathrm{Cd}(\mathrm{OH})_{2}$ (Ihsanullah et al. 2015). On the other hand, nickel is predominantly present in the $\mathrm{pH}$ range $2-3$ as $\mathrm{Ni}^{2+}$ but at higher $\mathrm{pH}$ range (4.5-6), partial hydrolysis of the metal ions occurs, and the removal of nickel is possibly accomplished by simultaneous precipitation of $\mathrm{Ni}(\mathrm{OH})_{2}$ and sorption of $\mathrm{Ni}(\mathrm{OH})^{+}$(Abdel-Ghani and El-Chaghaby 2014). The biosorption experiments on 

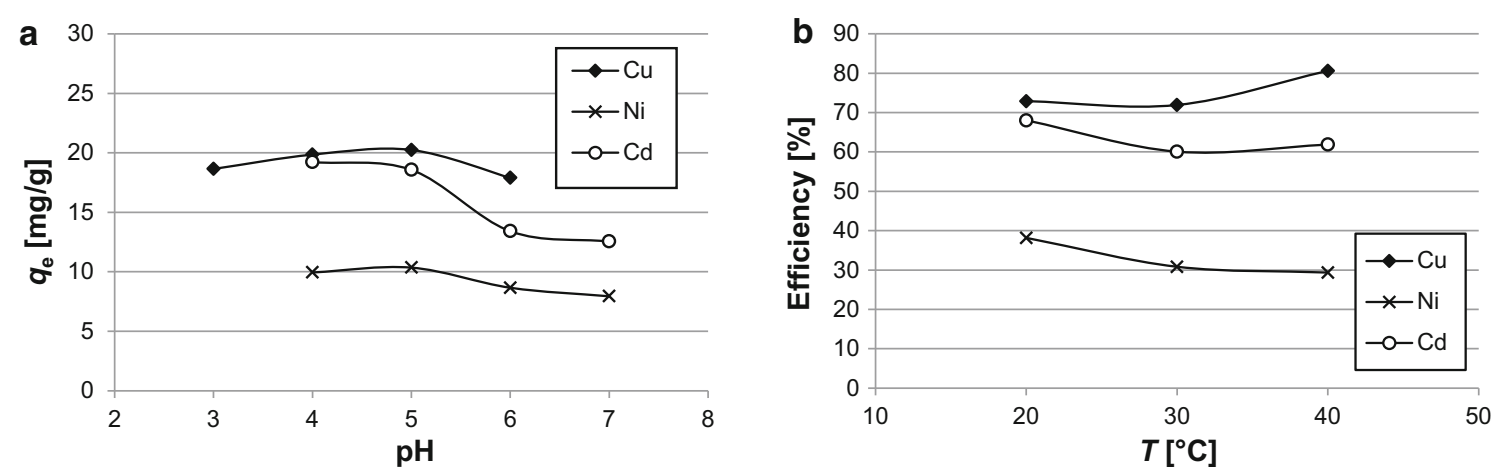

Fig. 2 The effect of initial $\mathrm{pH}(\mathbf{a})$ and temperature (b) on biosorption of $\mathrm{Cu}^{2+}, \mathrm{Ni}^{2+}$ and $\mathrm{Cd}^{2+}$ ions from drinking water by alginate-immobilised C. sorokiniana (initial metal concentration of $25 \mathrm{mg} / \mathrm{L}$, contact time of $180 \mathrm{~min}$ )

nickel in this study were not executed at $\mathrm{pH}>7$ to avoid metal ion precipitation. Maximum capacity of $\mathrm{Ni}^{2+}$ biosorption was $10.35 \mathrm{mg} / \mathrm{g}$, and the maximum efficiency was $41.63 \%$ (both at $\mathrm{pH} 5$ ). The highest capacities for $\mathrm{Cu}^{2+}$ and $\mathrm{Ni}^{2+}$ ions were obtained at $\mathrm{pH} 5$, and because the capacity for $\mathrm{Cd}^{2+}$ ions at $\mathrm{pH} 5$ was close to that at $\mathrm{pH} 4$, the appropriate $\mathrm{pH}$ for further experiments, at which the optimum removal efficiencies can be achieved, is suggested as being $\mathrm{pH} 5$.

The reactions of the metal ions within the solution with the biosorbent can be described by the following equilibrium (Eq. 11) (Bayramoğlu and Yakup Arıca 2009):

$H_{n} B+M n^{+1} \leftrightarrow M B+n H^{+}$

where $M$ denotes the metal, $n$ its charge and $B$ the available metal binding sites (functional groups) on the biosorbent. According to this equation, $\mathrm{pH}$ affects metal biosorption because of the competitive effect between the metal ions and $\mathrm{H}_{3} \mathrm{O}^{+}$ions for the same active metal binding sites (Onyancha et al. 2008). At low pH values, the $\mathrm{H}_{3} \mathrm{O}^{+}$ion concentration exceeds the concentrations of the metal ions; therefore, functional groups, i.e. ligands, are closely associated with the hydronium ions which occupy free binding sites and repulsive forces limit the approach of the metal ions. With increasing $\mathrm{pH}$, the competing effect of $\mathrm{H}_{3} \mathrm{O}^{+}$ ions decreases. More functional groups would be exposed and thus negative charges would result and attraction between negative charges and the metals would increase biosorption (Kaewsarn and Yu 2001; Sar1 and Tuzen 2009).

The same $\mathrm{pH}$ as in this study was found to be optimal in previous studies on heavy metal biosorption by alginateimmobilised algal cells. Bayramoğlu and Yakup Arıca (2009) found that biosorption of $\mathrm{Cu}^{2+}, \mathrm{Zn}^{2+}$ and $\mathrm{Ni}^{2+}$ ions by the alginate-immobilised Scenedesmus quadricauda showed the highest values at $\mathrm{pH} 5$. The same value was found to be the most appropriate for $\mathrm{Ni}^{2+}$ biosorption by immobilised Chlorella vulgaris (Al-Rub et al. 2004). However, a slightly lower $\mathrm{pH}$ value (4.5) was used for the removal of $\mathrm{Ni}^{2+}$ and $\mathrm{Cu}^{2+}$ by sodium alginate-immobilised C. vulgaris cells (Mehta and Gaur 2001).

The temperature of the biosorption medium can be important for metal biosorption by algal cells and can affect the removal efficiencies of heavy metals. The effect of temperature on the removal of $\mathrm{Cu}^{2+}, \mathrm{Ni}^{2+}$ and $\mathrm{Cd}^{2+}$ ions (at the initial concentration $25 \mathrm{mg} / \mathrm{L}$ for each metal) by immobilised algae is shown in Fig. $2 b$.

The biosorption capacity for $\mathrm{Cu}^{2+}$ ions increased from 15.45 to $16.56 \mathrm{mg} / \mathrm{g}$, and the removal efficiency from $72.91 \%$ to $80.61 \%$ as temperature was increased from 20 to $40{ }^{\circ} \mathrm{C}$. According to Sarı and Tuzen (2009), the increase in biosorption with rise in temperature may be caused by the strengthening of biosorptive forces between the active sites of the biosorbents and sorbate species, and between adjacent molecules of the sorbed phase. The effect may also be caused by the fact that at higher temperatures, an increase in active sites occurs because of bond rupture (Aksu 2002).

The maximum biosorption capacity of $\mathrm{Ni}^{2+}$ ions, $9.21 \mathrm{mg} / \mathrm{g}$, was found at $20^{\circ} \mathrm{C}$, decreasing with temperature (up to $40{ }^{\circ} \mathrm{C}$ ) to $6.57 \mathrm{mg} / \mathrm{g}$. Similarly, the biosorption capacity and efficiency for $\mathrm{Cd}^{2+}$ ions decreased in part when the temperature increased from 20 to $30^{\circ} \mathrm{C}$, but the capacity at $40{ }^{\circ} \mathrm{C}$ was similar to that at $30{ }^{\circ} \mathrm{C}$. Adsorption is generally an exothermic process. The decrease in biosorption efficiency with increase in temperature is caused, most probably, by the desorption tendencies of heavy metals from biosorbent surfaces (Bulgariu and Bulgariu 2012). As in this study, the removal percentage of cadmium decreased with rising temperatures in the biosorption study performed by Aksu (2001). However, since in our study there were no drastic decreases or increases in biosorption capacities with temperature during biosorptions of the chosen metals by alginate-immobilised $C$. sorokiniana, it was concluded that a temperature range of $20-30{ }^{\circ} \mathrm{C}$ allows sufficient removal efficiencies. 
Effect of initial metal concentration on single-metal systems

In order to study the effect of initial metal concentration on biosorption capacity by alginate-immobilised $C$. sorokiniana, experiments with different concentrations of $\mathrm{Cu}^{2+}$, $\mathrm{Ni}^{2+}$ and $\mathrm{Cd}^{2+}$ metal ions in the biosorption medium were performed, wherein the initial metal concentrations were varied within a range of 5-320 $\mathrm{mg} / \mathrm{L}$.

As seen in Fig. 3, the biosorption capacities of all the tested metals increased with increases in the initial metal concentration, whereby the equilibrium metal concentration also increased. Higher initial concentrations provided the driving force for overcoming mass transfer resistance of a metal ion between the aqueous solution and the solid, thus increasing the metal uptake. In addition, increasing initial metal ion concentrations also increases the number of collisions between metal ions and sorbent, which enhances the sorption process (Kumar and Das 2012; Onyancha et al. 2008). The experimental maximum biosorption capacities obtained during biosorptions of $\mathrm{Cu}^{2+}, \mathrm{Ni}^{2+}$ and $\mathrm{Cd}^{2+}$ ions by alginate-immobilised $C$. sorokiniana cells were found to be $150.07,48.87$ and $101.73 \mathrm{mg} / \mathrm{g}$ biosorbent, respectively. These results indicate that biosorption capacities for the metals tested followed the order: $\mathrm{Cu}^{2+}>\mathrm{Cd}^{2+}>\mathrm{Ni}^{2+}$. A similar order of biosorption capacities was noticed in a previous study on the biosorption of heavy metals using different types of algae conducted by Romera et al. (2007). They claimed that the differences when binding metal ions to active sites of the cell wall, i.e. differences in capacities, is closely related to certain intrinsic metal properties such as the ionic radii, atomic weights and electro-negativities of atoms. Moreover, the properties of the biosorbents, for instance structure, functional groups and surface properties, also play important roles during this process.

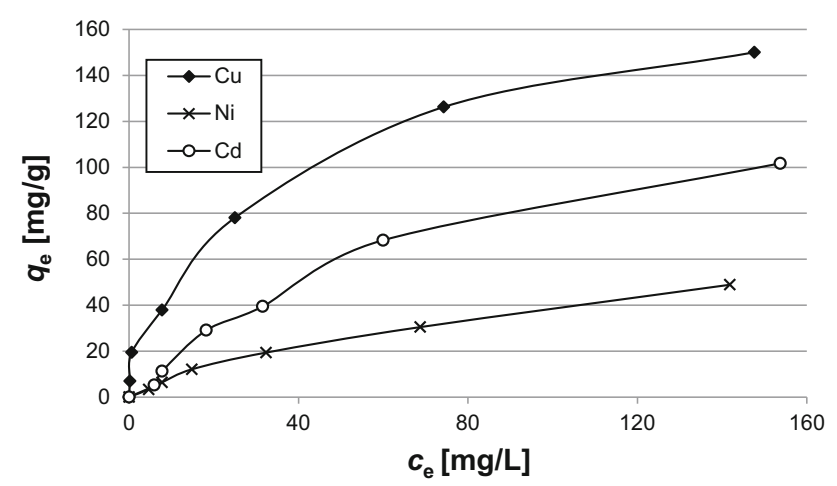

Fig. 3 The equilibrium biosorption capacities as functions of equilibrium concentrations for $\mathrm{Cu}^{2+}, \mathrm{Ni}^{2+}$ and $\mathrm{Cd}^{2+}$ removal from drinking water by alginate-immobilised $C$. sorokiniana $(\mathrm{pH}=5$, contact time of $180 \mathrm{~min}$ )
When studying the effects of initial metal concentrations on biosorptions, the highest removal yields achieved for $\mathrm{Cu}^{2+}, \mathrm{Ni}^{2+}$ and $\mathrm{Cd}^{2+}$ were 97.10, 50.94 and $64.61 \%$, respectively. In general, when increasing initial metal concentrations, the removal yields decreased, as the available sites on the surfaces of the biosorbents became saturated and further adsorptions of the metal ions prevented (Onyancha et al. 2008). Despite the good maximum biosorption capacities achieved, at higher initial metal concentrations when testing, the toxicity effects of these metals were observed on cells of $C$. sorokiniana. These could be seen in the ways that the algal beads lost their green colour as the number of cells, and thus the content of chlorophyll, decreased. The lowest toxicity effect on algal cells was noticed in the case of $\mathrm{Cd}^{2+}$ ions, whilst $\mathrm{Ni}^{2+}$ and $\mathrm{Cu}^{2+}$ ions showed slightly higher toxicities to $C$. sorokiniana. Although insufficient information is available on the genetics of metal uptake and resistance in algae and the mechanisms remain largely unknown, the biosorption of heavy metals by immobilised algae presents a promising alternative in regard to other biosorption systems. However, when working with live algal cells, the toxicity effect on the algal cells cannot be ignored; therefore, optimum initial metal concentrations are necessary for determination regarding each new biosorption system, as no particular concentration can be specified as applicable to all species.

Comparisons between capacities achieved during this investigation with previous studies on metal removal by alginate-immobilised $C$. sorokiniana are almost impossible, as there have been no studies with these algae species immobilised on such a carrier. In addition, most studies with other algae were performed with dead algal cells. However, the capacities for $\mathrm{Cu}^{2+}$ and $\mathrm{Ni}^{2+}$ ions during these experiments were higher than those capacities achieved during the biosorptions of these two metals by Scenedesmus quadricauda immobilised within the same matrix, wherein the maximum biosorption capacities were found to be 75.6 and $30.4 \mathrm{mg} / \mathrm{g}$ biosorbent, respectively (Bayramoğlu and Yakup Arıca 2009). In another study, the biosorption capacity of Chlorella sp. for $\mathrm{Cu}^{2+}$ ions after $6 \mathrm{~h}$ of biosorption in an alginate-immobilised system was even lower, at $33.4 \mathrm{mg} / \mathrm{g}$ (Wan Maznah et al. 2012). On the other hand, during the removal of $\mathrm{Ni}^{2+}$ and $\mathrm{Cu}^{2+}$ ions by alginate-immobilised Chlorella vulgaris, the capacity for $\mathrm{Ni}^{2+}$ was around $110 \mathrm{mg} / \mathrm{g}$ and was higher than the capacity for $\mathrm{Cu}^{2+}(65 \mathrm{mg} /$ g) (Mehta and Gaur 2001). In one of the rare studies on $C$. sorokiniana cells (non-immobilised), which have been proven to be highly resistant to heavy metals such as $\mathrm{Cd}^{2+}$, these algae were capable of taking up the heavy metal ions $\mathrm{Cd}^{2+}$, $\mathrm{Zn}^{2+}$ and $\mathrm{Cu}^{2+}$ at 43,42 and $46.4 \mathrm{mg} / \mathrm{g}$ dry weights, respectively (Yoshida et al. 2006). Otherwise, the capacities from the present study were higher, probably because of the immobilisation of algal cells. 
Table 2 Kinetic parameters for pseudo-second and pseudo-first order obtained from the biosorptions of $\mathrm{Cu}^{2+}, \mathrm{Ni}^{2+}$ and $\mathrm{Cd}^{2+}$ ions from drinking water by alginate-immobilised $C$. sorokiniana

\begin{tabular}{|c|c|c|c|c|c|c|c|}
\hline \multirow[t]{2}{*}{ Metal $^{\mathrm{a}}$} & \multicolumn{3}{|c|}{ Pseudo-second order } & \multicolumn{3}{|c|}{ Pseudo-first order } & \multirow[t]{2}{*}{$q_{\mathrm{e}, \exp }[\mathrm{mg} / \mathrm{g}]$} \\
\hline & $k_{2}[\mathrm{~g} /(\mathrm{mg} * \min )]$ & $q_{\mathrm{eq}, 2}[\mathrm{mg} / \mathrm{g}]$ & $R^{2}$ & $k_{1}\left[\min ^{-1}\right]$ & $q_{\mathrm{eq}, 1}[\mathrm{mg} / \mathrm{g}]$ & $R^{2}$ & \\
\hline $\mathrm{Cu}^{2+}$ & 0.0019 & 39.84 & 0.9986 & 0.0200 & 24.57 & 0.8914 & 37.85 \\
\hline $\mathrm{Ni}^{2+}$ & 0.0054 & 20.24 & 0.9992 & 0.0312 & 13.27 & 0.8550 & 19.34 \\
\hline $\mathrm{Cd}^{2+}$ & 0.0050 & 30.03 & 0.9988 & 0.0315 & 16.71 & 0.7491 & 29.08 \\
\hline
\end{tabular}

${ }^{a}$ Initial metal concentration of $50 \mathrm{mg} / \mathrm{L}, \mathrm{pH}=5$

\section{The impacts of repeated biosorption-desorption cycles on single-metal systems}

In order to study the impacts of repeated biosorption cycles on algae and removal efficiency, and to determine the reusability of the used biosorbent, five biosorption-desorption cycles were conducted with initial concentrations of each metal of $25 \mathrm{mg} / \mathrm{L}$ (at $\mathrm{pH}$ value 5 , contact time $180 \mathrm{~min}$ ). The results show that the removal efficiencies varied during the cycles and somewhere even increased as in the cases of $\mathrm{Cd}^{2+}$ and $\mathrm{Cu}^{2+}$ removal. This improvement may be attributed to the fact that regeneration or desorption using acid could free up more active sites by removing some contaminants that might have been bound previously to the algal cells (Al-Rub et al. 2004). After each desorption, the alginate beads were treated with $2 \% \mathrm{CaCl}_{2}$ solution in order to strengthen the algal beads; thus, the number of active sites present on the biosorbent could change.

The removal efficiencies for all three metals after five biosorption-desorption cycles performed by immobilised algal beads generally decreased by 5-10\%, compared with the highest efficiency achieved $\left(91.70 \%\right.$ for $\mathrm{Cu}^{2+}$ ions, $39.26 \%$ for $\mathrm{Ni}^{2+}$ ions and $60.3 \%$ for $\mathrm{Cd}^{2+}$ ions). The capacities achieved for the $\mathrm{Cu}^{2+}$ ions were within the range of $17.10-22.21 \mathrm{mg} / \mathrm{g}$, for $\mathrm{Ni}^{2+}$ between 8.17 and $9.55 \mathrm{mg} /$ $\mathrm{g}$ and for $\mathrm{Cd}^{2+} 11.04-12.75 \mathrm{mg} / \mathrm{g}$. A trend of decreasing efficiency with the number of performed cycles was also noticed in the cases of biosorption capacities.

After five cycles, a small decrease in algal cell numbers was observed; thus, the removal efficiency consequently decreased. This effect was noticed as being strongest in the cases of those experiments performed on $\mathrm{Cu}^{2+}$ and $\mathrm{Ni}^{2+}$ removal. When algal beads were stored for some days within a growth medium, the algal cells slowly regenerated. Nevertheless, five or even more cycles could be efficiently implemented with alginate-immobilised cells of C. sorokiniana.

\section{Biosorption kinetics for single-metal systems}

In order to clarify the biosorption kinetics of the $\mathrm{Cu}^{2+}$, $\mathrm{Ni}^{2+}$ and $\mathrm{Cd}^{2+}$ ions by alginate-immobilised $C$. sorokini$a n a$, pseudo-first-order and pseudo-second-order kinetic models were applied to the experimental data. Biosorption kinetics is expressed as the solute removal rate that controls the residence time of the sorbate at the solid-solution interface (Samuel et al. 2013). A comparison of the kinetic parameters estimated from the pseudo-first and pseudosecond-order kinetic models (Eqs. 9 and 10) and experimental biosorption capacities obtained at $50 \mathrm{mg} / \mathrm{L}$ of initial metal concentration is shown in Table 2. The correlation coefficients for the pseudo-second-order model were $>0.9986$, whilst for the pseudo-first-order the $R^{2}$ values were within the range of $0.7491-0.8914$. High correlation coefficients for the pseudo-second-order model for all three metals suggest that this model provides a better fit to the experimental data than a first-order model. It can be seen from Table 2 that the theoretical biosorption capacities $\left(q_{\text {eq,2 }}\right)$ of the pseudo-second-order kinetic model were closer to the experimental values $\left(q_{\mathrm{e}, \mathrm{exp}}\right)$ than the values of pseudo-first-order for all the heavy metals studied. Therefore, it can be concluded that the pseudo-first-order kinetic model is unsuitable for the biosorption of chosen metals onto alginate-immobilised $C$. sorokiniana and that biosorption follows the kinetics of the pseudo-second-order model. The rate-controlling step during the biosorption process is assumed to be a chemical sorption involving valance forces through sharing or exchanging electrons between functional groups of biosorbent and metals (Onyancha et al. 2008; Samuel et al. 2013).

\section{Biosorption isotherm models for single-metal systems}

The biosorption mechanism of metal ions by immobilised algae is quite complex, so analysis of equilibrium data are important for better understanding this process. Heavy metal sorption data are typically described and modelled by adsorption isotherms which are characterised by constants, the values of which express the surface properties and affinity of the biosorbent (Aksu 2001). In this study, four biosorption isotherm models were selected to fit the equilibrium experimental data of the biosorption system in order to predict the biosorption efficiency and potential of an adsorbent: Langmuir, Freundlich, Dubinin-Raduskhevich and Redlich-Peterson (see Table 1, Eqs. 5-8).

The parameters of the chosen isotherm models are collated in Table 3 . The values of correlation coefficients $\left(R^{2}\right)$ show that the biosorption isotherm data of the heavy metals 
Table 3 The constants and correlation coefficients obtained from Langmuir, Freundlich, Dubinin-Raduskhevich and Redlich-Peterson isotherm models for the biosorptions of $\mathrm{Cu}^{2+}, \mathrm{Ni}^{2+}$ and $\mathrm{Cd}^{2+}$ by alginate-immobilised $C$. sorokiniana

\begin{tabular}{llll}
\hline Metal & $\mathrm{Cu}^{2+}$ & $\mathrm{Ni}^{2+}$ & $\mathrm{Cd}^{2+}$ \\
\hline Isotherm constants & & & \\
Freundlich & & & \\
$\quad K_{\mathrm{F}}\left[(\mathrm{mg} / \mathrm{g})(\mathrm{mg} / \mathrm{L})^{\mathrm{n}}\right]$ & 19.8000 & 1.8580 & 4.4980 \\
$n$ & 2.4200 & 1.5130 & 1.5950 \\
$R^{2}$ & 0.9899 & 0.9968 & 0.9747 \\
Langmuir & & & \\
$q_{\mathrm{m}}[\mathrm{mg} / \mathrm{g}]$ & 179.90 & 86.49 & 164.50 \\
$b[\mathrm{~L} / \mathrm{mg}]$ & 0.0324 & 0.0088 & 0.0108 \\
$R_{\mathrm{L}}{ }^{2}$ & 0.3858 & 0.6726 & 0.6416 \\
$R^{2}$ & 0.9865 & 0.9943 & 0.9942 \\
Dubinin-Raduskhevich & & & \\
$K_{\mathrm{DR}}\left[\mathrm{mol} / \mathrm{J}^{2}\right]$ & 0.5233 & 1.0510 & 1.1000 \\
$q_{\mathrm{m}}[\mathrm{mg} / \mathrm{g}]$ & 157.30 & 54.33 & 119.30 \\
$E[\mathrm{~kJ} / \mathrm{mol}]$ & 0.9775 & 0.6897 & 0.6742 \\
$R^{2}$ & 0.9661 & 0.9417 & 0.9771 \\
Redlich-Peterson & & & \\
$K_{\mathrm{RP}}[\mathrm{L} / \mathrm{g}]$ & 87.14 & 1.43 & 1.84 \\
$a_{\mathrm{RP}}[\mathrm{L} / \mathrm{mg}]$ & 3.8220 & 0.2201 & 0.0180 \\
$n$ & 0.6140 & 0.5374 & 0.9019 \\
$R^{2}$ & 0.9906 & 0.9981 & 0.9933 \\
\hline
\end{tabular}

* The $R_{\mathrm{L}}$ value was calculated at $50 \mathrm{mg} / \mathrm{L}$ of initial metal concentration studied can be well represented by the Freundlich, Langmuir and Redlich-Peterson isotherm model. The maximum theoretical biosorption capacities for $\mathrm{Cu}^{2+}, \mathrm{Ni}^{2+}$ and $\mathrm{Cd}^{2+}$ ions calculated from the Langmuir equation were 179.90, 86.49 and $164.50 \mathrm{mg} / \mathrm{g}$ biosorbent, respectively. The equilibrium biosorption constant $(b)$ related to the affinity of the binding sites was the highest in the case of $\mathrm{Cu}^{2+}$ biosorption $(0.0324 \mathrm{~L} / \mathrm{mg})$, and the lowest in $\mathrm{Ni}^{2+}$ biosorption. Thus, the affinities for the $\mathrm{Cu}^{2+}$ ions were evidently higher than those of the other two metals. Furthermore, the dimensionless separation factor, $R_{\mathrm{L}}$ was calculated according to Eq. 2 in order to predict the affinity between the sorbate and sorbent. The values of the dimensionless separation factors for $\mathrm{Cu}^{2+}, \mathrm{Ni}^{2+}$ and $\mathrm{Cd}^{2+}$ ions calculated at $50 \mathrm{mg} / \mathrm{L}$ of initial metal concentration were within the range of $0<R_{\mathrm{L}}<1$ (Table 3), which indicates that the biosorbent is a favourable adsorbent for the removal of these ions from drinking water solutions. As already mentioned, the Langmuir model refers to a monolayer sorption of heavy metal ions which take place at the functional groups on a surface containing a limited number of binding sites, whilst the Freundlich equation refers to sorption on heterogeneous surfaces (Bulgariu and Bulgariu 2012; Sar1 and Tuzen 2009). The heterogeneity factor $n$, determined by using the Freundlich equation, was in the case of $\mathrm{Cu}^{2+}$ biosorption ions 2.4200 , whilst for $\mathrm{Ni}^{2+}$ and $\mathrm{Cd}^{2+}$ ions the values were lower and quite close to each other. The correlation coefficients for Freundlich isotherms were $>0.9747$, whereas similar or even higher values were calculated in the cases of the Langmuir and Redlich-Peterson isotherms.

The Redlich-Peterson model was used, since it is capable of representing adsorption equilibrium over a wide concentration range. The Redlich-Peterson constants $K_{\mathrm{RP}}$ [L/g] and $a_{\mathrm{RP}}[\mathrm{L} / \mathrm{mg}]$ were found to be 87.14 and 3.822 for $\mathrm{Cu}^{2+}$ ions, 1.43 and 0.2201 for $\mathrm{Ni}^{2+}$ and 1.84 and 0.0180 for $\mathrm{Cd}^{2+}$ ions, respectively.

The Dubinin-Radushkevich (D-R) isotherm is also widely applied in adsorption studies because it does not assume a homogeneous surface or constant adsorption potential. However, the D-R adsorption isotherm model did not fit very well to the experimental data obtained in this study, as the correlation coefficients were significantly lower (0.9417-0.9771) than those of the other three models. The mean free biosorption energies $E[\mathrm{~kJ} / \mathrm{mol}]$ for $\mathrm{Cu}^{2+}, \mathrm{Ni}^{2+}$ and $\mathrm{Cd}^{2+}$ ions, calculated from D-R constants $\left(K_{\mathrm{DR}}\right)$ by Eq. 3, were found to be $<8 \mathrm{~kJ} / \mathrm{mol}$.

As three of the four isotherm models used were suitable for describing the biosorption equilibriums of $\mathrm{Cu}^{2+}$, $\mathrm{Ni}^{2+}$ and $\mathrm{Cd}^{2+}$ ions by alginate-immobilised $C$. sorokiniana within the studied concentration range, it can be assumed that both monolayer biosorption and heterogeneous surface biosorption occur during biosorption experiments by immobilised algae. Such a complicated mechanism of biosorption was previously noticed for $\mathrm{Ni}^{2+}$ biosorption on C. vulgaris (Aksu 2002). 


\section{Characterisation of the biosorbents for single-metal systems}

Scanning electron microscopy (SEM), energy dispersive $\mathrm{X}$-ray spectroscopy (EDS) and Fourier transform infrared spectroscopy (FTIR) analyses are the most useful methods for the surface characterisation and elemental analysis of materials (Saleh and Gupta 2012a, b), especially for those materials that are involved in adsorption studies. SEM and EDS analyses were therefore applied to study the surface morphologies of the biosorbents after the biosorptions of each metal. The SEM images of alginate beads exposed to $\mathrm{Cu}^{2+}, \mathrm{Ni}^{2+}$ or $\mathrm{Cd}^{2+}$ ions presented in Fig. 4 show that the surfaces of such beads were relatively dynamic and rough compared to the unexposed beads, the surfaces of which were more uniform and smooth. The EDS spectra of the alginate-immobilised $C$. sorokiniana beads exposed to
$\mathrm{Cu}^{2+}, \mathrm{Ni}^{2+}$ or $\mathrm{Cd}^{2+}$ ions confirmed the presence of these ions on the biosorbent's surface. The peak for gold within the EDS spectra occurred because of gold sputtered on the surfaces of the samples. Besides the metal, the spectra also showed peaks for $\mathrm{Ca}^{2+}, \mathrm{C}$ and $\mathrm{O}$. This can be explained by the chemical composition of the algal beads. Alginate, i.e. alginic acid, is a heteropolysaccharide consisting of $1 \rightarrow 4$ linked $\beta$-D-mannuronic acid and its C-5 epimer $\alpha$-L-guluronic acid (Pawar and Edgar 2012) and is thus rich in C and $\mathrm{O}$. Algae contain these and many other elements, as the main components of the cell walls are peptidoglycan, teichuronic acid, teichoic acid, polysaccharides and proteins, which contain various functional groups (Aksu and Dönmez 2006). The presence of $\mathrm{Ca}^{2+}$ ions appears from the $\mathrm{CaCl}_{2}$ used during the preparation procedure of the biosorbent as the hardening agent of the alginate beads. As the alginate beads were, before the biosorption a

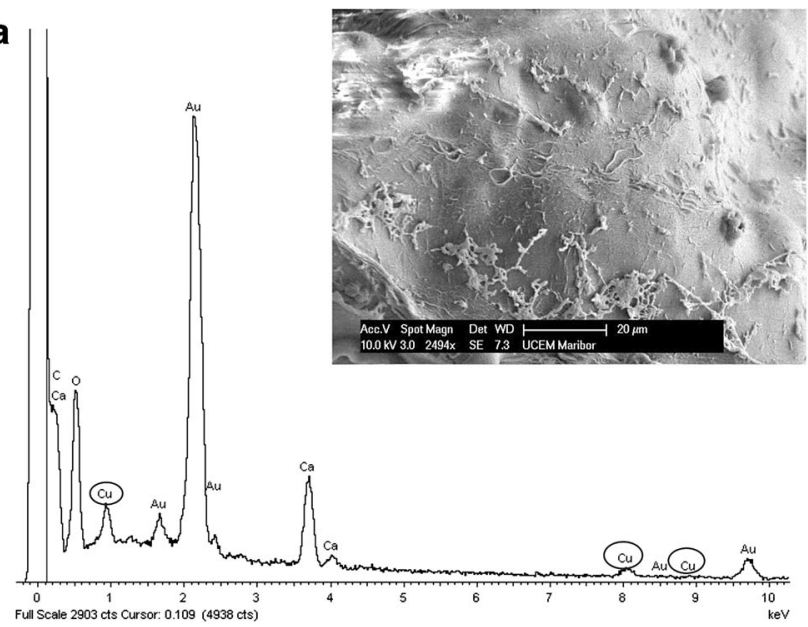

b

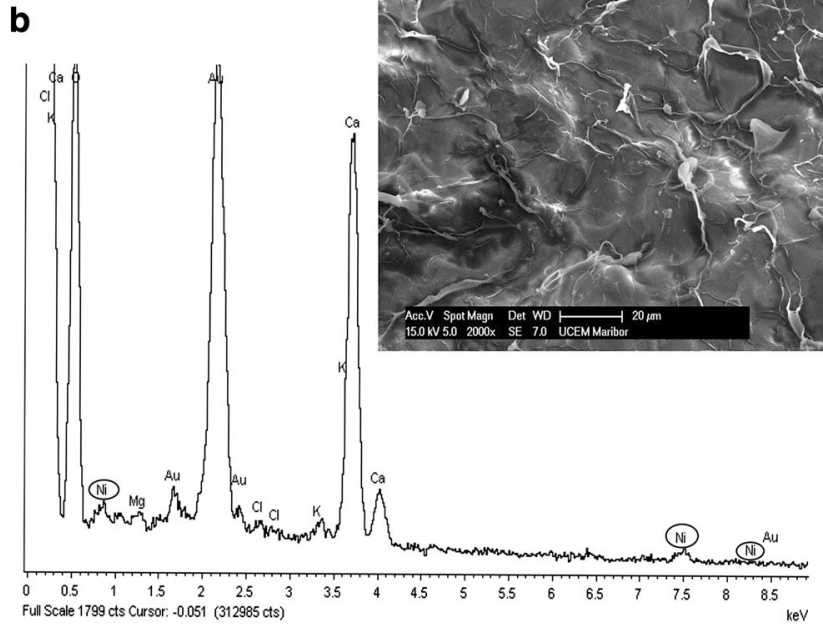

C

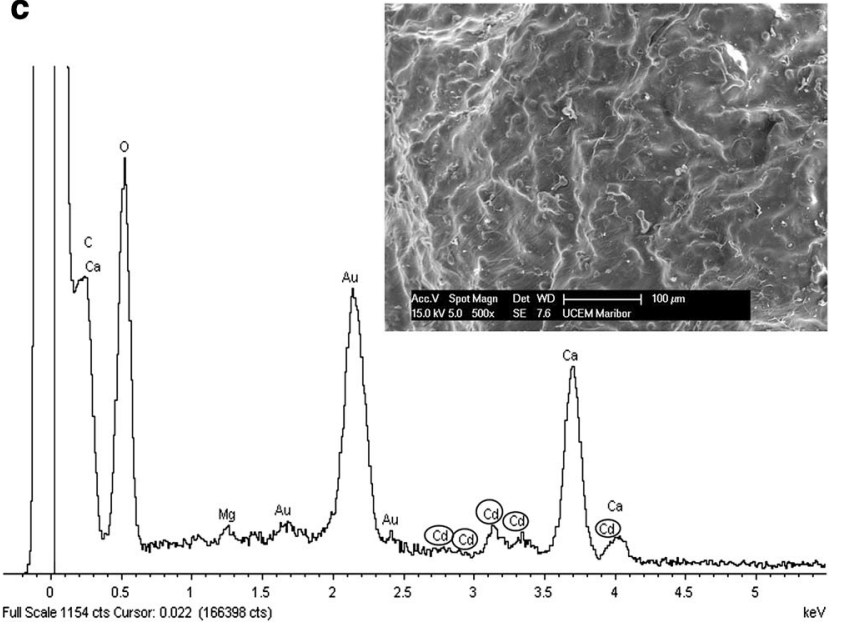

d

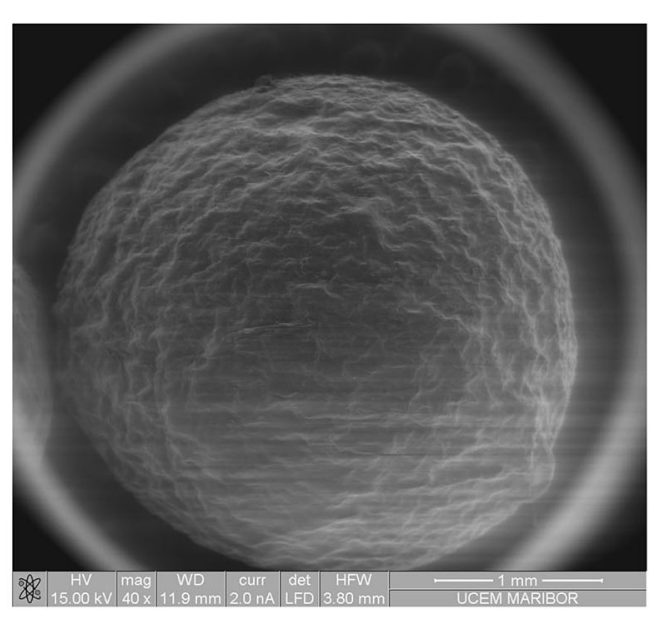

Fig. 4 SEM and EDS analyses of alginate-immobilised $C$. sorokiniana beads exposed to: $\mathbf{a ~} \mathrm{Cu}^{2+}, \mathbf{b ~ N i}{ }^{2+}, \mathbf{c} \mathrm{Cd}^{2+}$ ions and $\mathbf{d}$ shows an $\mathrm{SEM}$ image of the unexposed algal bead 
experiments, stored within a growth medium containing various compounds and rinsed with $\mathrm{NaCl}$ solution, residuals of $\mathrm{K}^{+}, \mathrm{Mg}^{2+}$ and $\mathrm{Cl}^{-}$ions were also found within the specimen.

In addition, some other basic properties such as specific surface area and pore sizes, the water content and the diameters of the algal beads were also determined in order to characterise the biosorbents before being used in these experiments. The specific surface area of the C. sorokiniana immobilised alginate beads was measured as $562.0034 \mathrm{~m}^{2} / \mathrm{g}$. The pore sizes of the beads amounted to $14.4130 \mathrm{~nm}$, and the pore volume was $1.8421 \mathrm{~cm}^{3} / \mathrm{g}$. The measured diameters of the algal beads were within the range of $3.5 \pm 0.5 \mathrm{~mm}$. The water content of the beads was determined after drying the sample until constant weight and was found to be around $98 \%$.

\section{Bi-metal and multi-metal biosorptions}

\section{Binary biosorption of $\mathrm{Cu}^{2+} / \mathrm{Ni}^{+}$}

The experiments on binary biosorption of $\mathrm{Cu}^{2+} / \mathrm{Ni}^{2+}$ by alginate-immobilised $C$. sorokiniana showed that the biosorption capacities for $\mathrm{Ni}^{2+}$ ions were considerably affected by the presence of $\mathrm{Cu}^{2+}$ ions within the drinking water solution (Fig. 5a; Table 4). The equilibrium uptake capacity of $\mathrm{Ni}^{2+}$ (at a constant initial $\mathrm{Ni}^{2+}$ conc. of $30 \mathrm{mg}$ / L) decreased noticeably with increasing concentrations of $\mathrm{Cu}^{2+}$ ions from 30 to $100 \mathrm{mg} / \mathrm{L}$ (Fig. 5a). The highest capacities of $\mathrm{Ni}^{2+}$ ions $(30.4 \mathrm{mg} / \mathrm{g})$ within the bi-metal solution were achieved in cases when the initial concentration of $\mathrm{Ni}^{2+}$ ions was the highest and that of $\mathrm{Cu}^{2+}$ the lowest (100 and $30 \mathrm{mg} / \mathrm{L}$, respectively). The increase in inhibition of $\mathrm{Ni}^{2+}$ biosorption with increase in concentration of $\mathrm{Cu}^{2+}$ in the solution implies that these two metals were competing for the binding sites present on the surface of the biosorbent. According to Flouty and Estephane (2012), the primary species involved in the biosorption mechanism of copper are the amino groups. However, the competition amongst different metal ions depends highly on ionic characteristics, and biosorption can also decrease with increasing ionic strength of the aqueous phase because of the presence of different cations within the solution (Onyancha et al. 2008). The greater the electronegativity or ionic radii, the greater the affinity usually is. Thus, as the ionic radius of $\mathrm{Cu}^{2+}$ ions is greater $(0.73 \AA)$ than that of $\mathrm{Ni}^{2+}$ ions $(0.69 \AA)$, a stronger physical affinity for $\mathrm{Cu}^{2+}$ ions is expected at the biosorption sites on the cells. However, inhibition of $\mathrm{Ni}^{2+}$ sorption due to $\mathrm{Cu}^{2+}$ ions was stronger than the inhibition of $\mathrm{Cu}^{2+}$ sorption by $\mathrm{Ni}^{2+}$, as the removal capacities and efficiencies for $\mathrm{Cu}^{2+}$ achieved at higher concentrations of $\mathrm{Ni}^{2+}$ were very similar to those at the lowest concentration (Fig. 5b). When both metals within the solution were at the same concentration (i.e. $30 \mathrm{mg} / \mathrm{L}$ ), the removal efficiency (capacity) for $\mathrm{Cu}^{2+}$ was $89.68 \%(21.47 \mathrm{mg} / \mathrm{g})$ and $39.66 \%(11.15 \mathrm{mg} / \mathrm{g})$ for the $\mathrm{Ni}^{2+}$ ions but when increasing the $\mathrm{Cu}^{2+}$ concentration up to $100 \mathrm{mg} / \mathrm{L}$, then the efficiency for $\mathrm{Ni}^{2+}$ decreased to $21.03 \%(5.45 \mathrm{mg} / \mathrm{g})$. On the other hand, the removal efficiency for $\mathrm{Cu}^{2+}$ ions at $100 \mathrm{mg} / \mathrm{L}$ of $\mathrm{Ni}^{2+}$ and $30 \mathrm{mg} / \mathrm{L}$ of $\mathrm{Cu}^{2+}$ was still higher than $85 \%$. Insignificant or low inhibitory effect of $\mathrm{Ni}^{2+}$ ions on $\mathrm{Cu}^{2+}$ sorption was
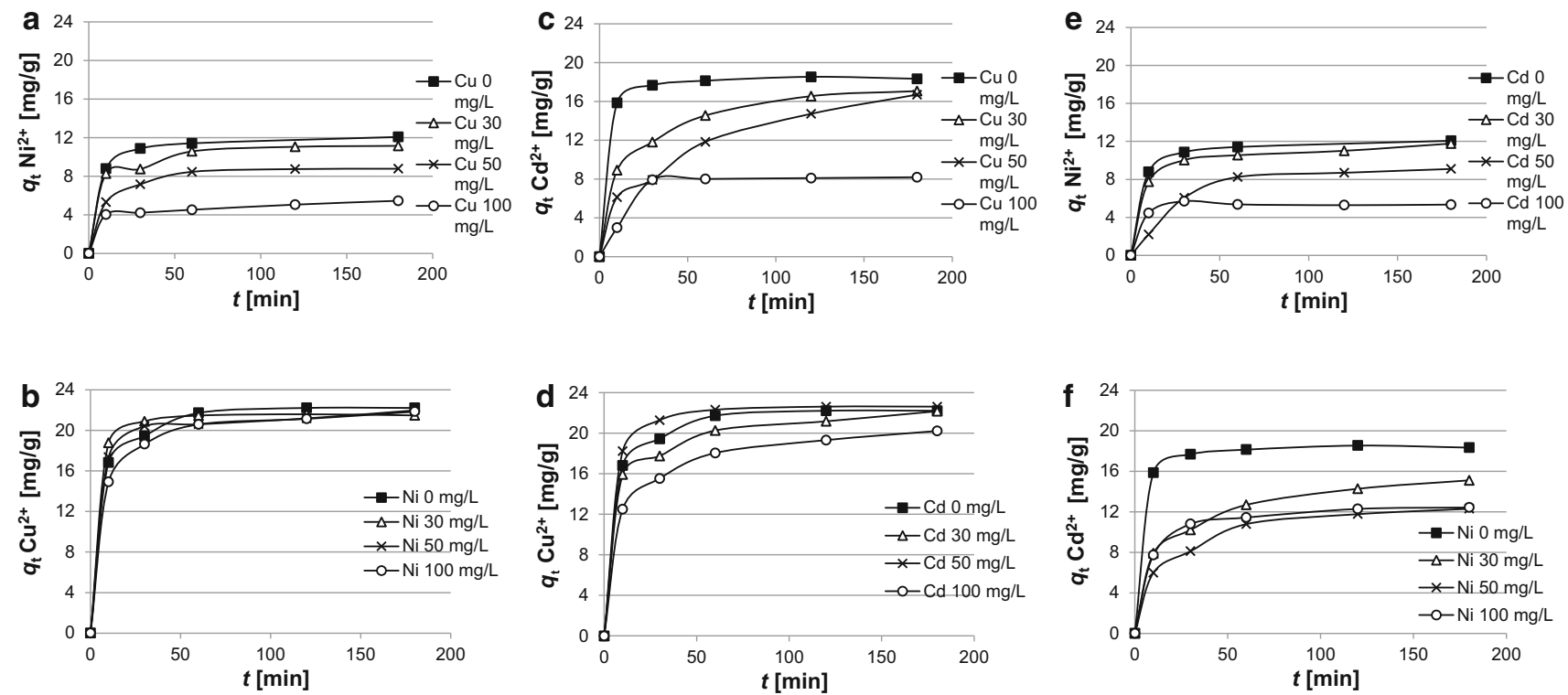

Fig. 5 The influences of: $\mathbf{a} \mathrm{Cu}^{2+}$ on $\mathrm{Ni}^{2+}$ biosorption, $\mathbf{b ~} \mathrm{Ni}^{2+}$ on $\mathrm{Cu}^{2+}$ biosorption, $\mathbf{c ~} \mathrm{Cu}^{2+}$ on $\mathrm{Cd}^{2+}$ biosorption, $\mathbf{d ~ C d} d^{2+}$ on $\mathrm{Cu}^{2+}$ biosorption, e $\mathrm{Cd}^{2+}$ on $\mathrm{Ni}^{2+}$ biosorption, $\mathbf{f ~} \mathrm{Ni}^{2+}$ on $\mathrm{Cd}^{2+}$ biosorption. Initial conc. of primary metal: $30 \mathrm{mg} / \mathrm{L}$ 
Table 4 Equilibrium biosorption capacities and removal efficiencies for the bi-metal and multi-metal systems of $\mathrm{Cu}^{2+}, \mathrm{Ni}^{2+}$ and $\mathrm{Cd}^{2+}$ ions depending on the initial metal concentrations

\begin{tabular}{|c|c|c|c|c|c|c|c|c|c|c|}
\hline \multirow[t]{2}{*}{ Metal system ${ }^{a}$} & \multicolumn{3}{|c|}{$c_{0}[\mathrm{mg} / \mathrm{L}]$} & \multicolumn{3}{|c|}{$q_{\mathrm{e}}[\mathrm{mg} / \mathrm{g}]$} & \multicolumn{3}{|c|}{ Efficiency (\%) } & \multirow{2}{*}{$\begin{array}{l}\text { Separation factor } \\
\alpha_{2}^{1}\end{array}$} \\
\hline & $\mathrm{Cu}^{2+}$ & $\mathrm{Cd}^{2+}$ & $\mathrm{Ni}^{2+}$ & $\mathrm{Cu}^{2+}$ & $\mathrm{Cd}^{2+}$ & $\mathrm{Ni}^{2+}$ & $\mathrm{Cu}^{2+}$ & $\mathrm{Cd}^{2+}$ & $\mathrm{Ni}^{2+}$ & \\
\hline \multirow[t]{9}{*}{$\mathrm{Cu}^{2+} / \mathrm{Ni}^{2+}$} & 30 & I & I & 22.21 & / & I & 91.70 & / & / & I \\
\hline & I & I & 30 & I & I & 12.07 & I & / & 49.70 & / \\
\hline & 30 & l & 30 & 21.47 & / & 11.15 & 89.68 & I & 39.66 & 13.22 \\
\hline & 50 & l & 30 & 39.96 & / & 8.77 & 78.27 & I & 32.59 & 7.45 \\
\hline & 100 & I & 30 & 68.96 & / & 5.45 & 71.40 & / & 21.03 & 9.38 \\
\hline & 30 & I & 50 & 21.97 & / & 15.60 & 87.12 & / & 31.36 & 14.80 \\
\hline & 30 & I & 100 & 21.84 & / & 30.40 & 85.18 & I & 34.60 & 10.86 \\
\hline & 50 & I & 50 & 35.32 & / & 15.31 & 69.60 & / & 30.78 & 5.15 \\
\hline & 100 & I & 100 & 67.67 & / & 19.54 & 67.30 & / & 18.93 & 8.82 \\
\hline \multirow[t]{9}{*}{$\mathrm{Cu}^{2+} / \mathrm{Cd}^{2+}$} & 30 & I & / & 22.21 & / & / & 91.69 & / & / & / \\
\hline & / & 30 & / & / & 18.33 & l & / & 73.40 & I & I \\
\hline & 30 & 30 & I & 22.16 & 17.06 & I & 85.30 & 62.31 & I & 3.51 \\
\hline & 50 & 30 & I & 36.54 & 16.70 & I & 91.50 & 64.09 & I & 6.03 \\
\hline & 100 & 30 & I & 67.12 & 8.18 & I & 76.44 & 25.84 & I & 9.31 \\
\hline & 30 & 50 & I & 22.62 & 25.53 & I & 85.25 & 52.65 & I & 5.20 \\
\hline & 30 & 100 & I & 20.22 & 24.86 & I & 90.11 & 28.23 & I & 23.16 \\
\hline & 50 & 50 & I & 39.13 & 15.11 & I & 91.53 & 32.64 & I & 22.30 \\
\hline & 100 & 100 & I & 59.91 & 19.82 & I & 75.81 & 23.55 & I & 10.17 \\
\hline \multirow[t]{9}{*}{$\mathrm{Cd}^{2+} / \mathrm{Ni}^{2+}$} & I & 30 & I & 1 & 18.33 & I & I & 73.40 & I & I \\
\hline & I & I & 30 & I & I & 12.07 & I & I & 49.70 & I \\
\hline & I & 30 & 30 & I & 15.10 & 11.77 & I & 63.03 & 42.08 & 2.35 \\
\hline & I & 50 & 30 & I & 25.25 & 9.10 & I & 64.55 & 31.91 & 3.89 \\
\hline & I & 100 & 30 & I & 53.78 & 5.35 & I & 53.78 & 18.57 & 6.41 \\
\hline & I & 30 & 50 & I & 12.30 & 17.65 & I & 49.56 & 41.29 & 1.41 \\
\hline & I & 30 & 100 & I & 12.43 & 26.63 & I & 50.85 & 29.97 & 2.42 \\
\hline & I & 50 & 50 & I & 23.18 & 24.15 & I & 61.18 & 39.18 & 2.45 \\
\hline & I & 100 & 100 & I & 31.87 & 16.62 & I & 39.54 & 18.33 & 2.86 \\
\hline \multirow[t]{17}{*}{$\mathrm{Cu}^{2+} / \mathrm{Cd}^{2+} / \mathrm{Ni}^{2+}$} & 30 & 30 & 30 & 24.30 & 12.59 & 8.25 & 84.51 & 47.41 & 32.43 & I \\
\hline & 30 & 30 & 50 & 18.03 & 10.48 & 10.39 & 71.02 & 38.81 & 22.89 & I \\
\hline & 30 & 30 & 100 & 19.37 & 11.73 & 21.29 & 78.01 & 45.23 & 24.41 & I \\
\hline & 50 & 50 & 30 & 9.94 & 16.86 & 2.45 & 46.30 & 40.39 & 9.81 & I \\
\hline & 50 & 30 & 30 & 30.09 & 10.09 & 19.22 & 75.99 & 35.75 & 69.89 & I \\
\hline & 100 & 30 & 30 & 73.27 & 13.85 & 4.42 & 76.72 & 48.10 & 17.41 & I \\
\hline & 30 & 50 & 50 & 76.82 & 18.18 & 7.66 & 93.50 & 41.84 & 25.84 & I \\
\hline & 30 & 50 & 30 & 34.98 & 20.36 & 14.68 & 84.22 & 45.81 & 32.64 & I \\
\hline & 30 & 100 & 30 & 21.63 & 41.37 & 5.77 & 89.01 & 47.11 & 22.48 & I \\
\hline & 50 & 30 & 50 & 62.92 & 18.11 & 20.81 & 75.81 & 62.00 & 23.55 & I \\
\hline & 50 & 50 & 50 & 35.91 & 21.46 & 13.09 & 83.99 & 48.11 & 29.66 & I \\
\hline & 100 & 30 & 50 & 72.92 & 10.48 & 15.91 & 77.29 & 35.82 & 37.65 & I \\
\hline & 50 & 30 & 100 & 33.02 & 11.97 & 32.66 & 89.32 & 44.41 & 37.16 & / \\
\hline & 100 & 50 & 30 & 79.35 & 16.90 & 6.39 & 88.30 & 36.60 & 27.94 & I \\
\hline & 30 & 50 & 100 & 19.67 & 20.92 & 25.51 & 74.74 & 43.79 & 29.28 & I \\
\hline & 50 & 100 & 30 & 32.73 & 37.63 & 2.64 & 80.12 & 41.39 & 11.17 & I \\
\hline & 30 & 100 & 50 & 16.11 & 36.29 & 10.71 & 66.89 & 41.10 & 27.59 & I \\
\hline
\end{tabular}

${ }^{a}$ The first metal in the bi-metal system represents the preferred metal (marked with 1) in the separation factor. For example, in the bi-metal system $\mathrm{Cu}^{2+} / \mathrm{Ni}^{2+}, \mathrm{Cu}^{2+}$ represents metal 1 and $\mathrm{Ni}^{2+}$ represents metal 2 
likewise reported by some other researchers (Flouty and Khalaf 2015; Mehta and Gaur 2001). In addition, they found that total metal $(\mathrm{Ni}+\mathrm{Cu})$ sorbed from the binary metal solution by immobilised Chlorella vulgaris always remained lower than the total sorption of individual metals from single-metal solutions, thereby suggesting strong competition between these ions for common binding sites on the biosorbent. The same can be said for the results obtained from these experiments (those at $30 \mathrm{mg} / \mathrm{L}$ of initial metal concentration).

Since experiments on single-metal systems show that pseudo-first-order kinetic model is inappropriate to describe biosorption of the chosen metals, the biosorption kinetics of bi-metal systems were studied only by using a pseudo-second-order kinetic model (data not shown). As in single-metal systems, the values of theoretical biosorption capacities for a $\mathrm{Cu}^{2+} / \mathrm{Ni}^{2+}$ system were in excellent agreement with the experimental ones (the correlation coefficients were higher than 0.9933) and the same applies to the other two bi-metal systems. The rate constants for pseudo-second-order biosorption $\left(k_{2}\right)$ in $\mathrm{Cu}^{2+} / \mathrm{Ni}^{2+}$ systems, with some exceptions, decreased with increasing initial concentration of the chosen metal, and the highest values for $\mathrm{Cu}^{2+}$ were obtained when both metals were in the solution at the lowest initial metal concentration.

The preference for $\mathrm{Cu}^{2+}$ ions in binary biosorption of $\mathrm{Cu}^{2+} / \mathrm{Ni}^{2+}$ by alginate-immobilised algae was also confirmed with the separation factors $\alpha_{2}^{1}$ (see Table 4), which were calculated by Eq. 4. Otherwise, when comparing the results of this experiment with the results of single-metal biosorption (at initial metal conc. $30 \mathrm{mg} / \mathrm{L}$ ), the removal efficiency for $\mathrm{Ni}^{2+}$ ions within a single-metal system was significantly higher (around $49 \%$ ), whilst the removal efficiency for $\mathrm{Cu}^{2+}$ was comparable.

\section{Binary biosorption of $\mathrm{Cu}^{2+} / \mathrm{Cd}^{2+}$}

The results of biosorption capacity, removal efficiency and separation factor obtained from biosorption of the bi-metal system $\mathrm{Cu}^{2+} / \mathrm{Cd}^{2+}$ for each of these two metals are collated in Table 4.

As can be seen, a preference for $\mathrm{Cu}^{2+}$ ions was observed in comparison with $\mathrm{Cd}^{2+}$ ions in biosorption by alginateimmobilised $C$. sorokiniana. Despite the ionic radius of $\mathrm{Cd}^{2+}$ being larger $(0.95 \AA)$ than that of $\mathrm{Cu}^{2+}(0.73 \AA)$, $\mathrm{Cu}^{2+}$ ions had a higher affinity than $\mathrm{Cd}^{2+}$ ions and the binding sites were first occupied by $\mathrm{Cu}^{2+}$ ions, and only the remaining sites were available for $\mathrm{Cd}^{2+}$ ions. Thus, the biosorption capacities for $\mathrm{Cu}^{2+}$ during this study were usually higher than those for $\mathrm{Cd}^{2+}$ except in the experiments where the concentration of $\mathrm{Cd}^{2+}$ ions was higher than that of $\mathrm{Cu}^{2+}$ ions. For example, when both metals were in solution at equal concentrations of $50 \mathrm{mg} / \mathrm{L}$, the biosorption capacity for $\mathrm{Cu}^{2+}$ ions was $39.13 \mathrm{mg} / \mathrm{g}$ and for $\mathrm{Cd}^{2+} 15.11 \mathrm{mg} / \mathrm{g}$. Higher selectivity for $\mathrm{Cu}^{2+}$ than for $\mathrm{Cd}^{2+}$ ions, when using C. sorokiniana cells as biosorbent, were also determined by Yoshida et al. (2006). They reported that $C$. sorokiniana cells could adsorb $\mathrm{Cd}^{2+}$ ions on the cell surface and also incorporate them intracellularly.

On the other hand, as seen from Fig. 5d, the biosorption of $\mathrm{Cu}^{2+}$ was not apparently affected by the presence of $\mathrm{Cd}^{2+}$ ions in the solution, although the concentration of $\mathrm{Cd}^{2+}$ ions was increasing. In addition, the removal efficiency for $\mathrm{Cu}^{2+}$ ions in the $\mathrm{Cu}^{2+} / \mathrm{Cd}^{2+}$ system was always greater than $75 \%$, whilst the efficiencies for $\mathrm{Cd}^{2+}$ ions varied from $23 \%$ up to $64 \%$. Otherwise, the biosorption capacities and the removal efficiencies for both metals involved in this bi-metal system were at their lowest concentrations quite close to those values obtained under the same conditions in a single-metal system. When increasing the concentration of one of the metals present within the solution, the differences also became greater.

In comparison to the $\mathrm{Cu}^{2+} / \mathrm{Ni}^{2+}$ system, several differences were observed in kinetics properties of the $\mathrm{Cu}^{2+}$ / $\mathrm{Cd}^{2+}$ system, since the rate constants of pseudo-second order, contrary to expectations, were not decreased with increasing initial metal concentration, and sometimes even increased. This indicates that the type of competing metal has an appreciable influence on biosorption properties. However, $\mathrm{Cu}^{2+}$ was more rapidly biosorbed than $\mathrm{Cd}^{2+}$, whereas in the case of $\mathrm{Cu}^{2+}$, the rate constants were generally higher.

\section{Binary biosorption of $\mathrm{Cd}^{2+} / \mathrm{Ni}^{2+}$}

In experiments on the biosorption of $\mathrm{Cd}^{2+} / \mathrm{Ni}^{2+}$ by alginate-immobilised algae, an inhibitory effect of $\mathrm{Cd}^{2+}$ ions was observed on $\mathrm{Ni}^{2+}$ biosorption. The equilibrium uptake of $\mathrm{Ni}^{2+}$ decreased regularly with increasing concentrations of $\mathrm{Cd}^{2+}$ ions (Fig. 5e; Table 4). However, when the concentration of $\mathrm{Ni}^{2+}$ ions in the solution increased, the inhibitory effect of $\mathrm{Cd}^{2+}$ ions was minimised. Otherwise, the decrease in uptake of $\mathrm{Cd}^{2+}$ ions at the initial concentration of $30 \mathrm{mg} / \mathrm{L}$ was much lower in the presence of higher $\mathrm{Ni}^{2+}$ concentrations. Thus, like the metals from previous bi-metal systems, these two metals also bound to the same sites on the biosorbent surface and competition between them occurred for free sites. The competition for free biosorbent sites amongst various metals has been reported in the literature to date, but limited to the binary biosorptions of nickel and cadmium. As in this study, Aksu and Dönmez (2006) investigated the sorption behaviour of cadmium and nickel ions on $C$. vulgaris. Only weaker 
competition in the adsorption capacity of nickel in the presence of cadmium was noticed, whilst the uptake of nickel was reduced much more by the addition of cadmium. Rodrigues et al. (2012) examined binary and ternary systems of $\mathrm{Ni}^{2+}, \mathrm{Zn}^{2+}$ and $\mathrm{Pb}^{2+}$ as competitive adsorbates using Arthrospira platensis and Chlorella vulgaris as biosorbents, whereas $\mathrm{Ni}^{2+}$ and $\mathrm{Zn}^{2+}$ interference during $\mathrm{Pb}^{2+}$ sorption was lower in contrast, probably because of preference for $\mathrm{Pb}^{2+}$. Flouty and Estephane (2012) studied the biosorption of a copper-lead system by algae Chlamydomonas reinhardtii. Interestingly, no competitive effect of $\mathrm{Pb}^{2+}$ on the biosorption of $\mathrm{Cu}^{2+}$ was identified during this study, indicating that these two metals were not competing for the same adsorption sites. According to Chong et al. (2000), $\mathrm{Ni}^{2+}$ removal by different microalgae species was suppressed by the presence of $\mathrm{Zn}^{2+}$ ions. In another study, $\mathrm{Cd}^{2+}$ and $\mathrm{Zn}^{2+}$ uptake by $C$. sorokiniana was progressively and negatively affected by $\mathrm{Cu}^{2+}$, indicating that this strain had a higher affinity for $\mathrm{Cu}^{2+}$ than for $\mathrm{Cd}^{2+}$ and $\mathrm{Zn}^{2+}$ (Yoshida et al. 2006).

Furthermore, the removal efficiencies for $\mathrm{Cd}^{2+}$ ions were, in almost all cases except at the highest initial metal concentration of $100 \mathrm{mg} / \mathrm{L}$, between 49 and $65 \%$, whilst the uptake of $\mathrm{Ni}^{2+}$ ions in the bi-metal solution was less efficient $(<50 \%)$. The capacities and the removal efficiencies obtained herein were poorer than those in the single-metal solutions. In addition, the smallest efficiencies and capacities were achieved in this system amongst all three tested bi-metal systems. The separation factors of the $\mathrm{Cd}^{2+} / \mathrm{Ni}^{2+}$ system were, in comparison with the other two binary systems, also considerably lower. The affinity for $\mathrm{Cd}^{2+}$ ions was, compared to $\mathrm{Ni}^{2+}$ ions, lower than the affinity for $\mathrm{Cu}^{2+}$ ions in regard to $\mathrm{Ni}^{2+}$ and $\mathrm{Cd}^{2+}$. Thus, the affinity order of metals tested in these bi-metal systems can be written as follows: $\mathrm{Cu}^{2+}>\mathrm{Cd}^{2+}>\mathrm{Ni}^{2+}$.

However, a kinetics study of collected data shows that rate constants of pseudo-second order for $\mathrm{Cd}^{2+}$ ions were the highest in single-metal system but in bi-metal systems they decreased considerably; thus, biosorption of $\mathrm{Cd}^{2+}$ ions in $\mathrm{Cd}^{2+} / \mathrm{Ni}^{2+}$ and $\mathrm{Cu}^{2+} / \mathrm{Cd}^{2+}$ systems was less effective than that of this metal alone. $\mathrm{Ni}^{2+}$ and $\mathrm{Cu}^{2+}$ in combination with $\mathrm{Cd}^{2+}$ in bi-metal systems apparently behaved as antagonists.

\section{Multi-metal biosorption of $\mathrm{Cu}^{2+} / \mathrm{Ni}^{2+} / \mathrm{Cd}^{2+}$}

The experiments on multi-metal biosorption by alginateimmobilised $C$. sorokiniana were carried out under the same conditions as the experiments on bi-metal systems. The results obtained from these experiments, the equilibrium capacities and efficiencies in regard to initial concentrations of each of the metals in the solution, are shown in Table 4.
In general, similar trends were found as in bi-metal systems. When the concentration of one of the metals increased (for example $\mathrm{Cu}^{2+}$ from 30 up to $100 \mathrm{mg} / \mathrm{L}$ ), and the other two remained constant $(30 \mathrm{mg} / \mathrm{L})$, the capacity for the primary metal also increased. The situation was different when the primary metal was at the lowest concentration in the solution $(30 \mathrm{mg} / \mathrm{L})$ and the other two metals were higher, one at 50 and another at $100 \mathrm{mg} / \mathrm{L}$ or the reverse. Then the highest capacity was found for the metal with the highest initial concentration in the solution. However, the capacities in multi-metal biosorption were lower compared to bi-metal and single-metal systems for almost all metals (see Table 4). Thus, increasing the number of co-metals in the solution decreased the biosorption capacities for the metals involved. For instance, the biosorption capacity (removal efficiency) for $\mathrm{Cd}^{2+}$ ions at the initial metal concentration of $30 \mathrm{mg} / \mathrm{L}$ was in the multi-metal system $12.59 \mathrm{mg} / \mathrm{g}(47.41 \%)$, in the bimetal system of $\mathrm{Cu}^{2+} / \mathrm{Cd}^{2+} 17.06 \mathrm{mg} / \mathrm{g}(62.31 \%)$ and for the $\mathrm{Cd}^{2+} / \mathrm{Ni}^{2+}$ system $15.10 \mathrm{mg} / \mathrm{g}(63.03 \%)$. The highest capacity, $18.33 \mathrm{mg} / \mathrm{g}(73.40 \%)$ for $\mathrm{Cd}^{+}$ions, was found in the single-metal system. A similar tendency was already noticed in a study on multi-metal biosorption of the $\mathrm{Ni}^{2+}$ / $\mathrm{Zn}^{2+} / \mathrm{Pb}^{2+}$ system (Rodrigues et al. 2012). The behaviour of metals tested in bi-metal and multi-metal systems in this study can be described as being the closest for antagonism (Aksu and Dönmez 2006). Biosorption of $\mathrm{Cu}^{2+}, \mathrm{Ni}^{2+}$ and $\mathrm{Cd}^{2+}$ ions in multi-metal systems, as in single and bi-metal systems, followed the kinetics of the pseudo-second-order model (correlation coefficients $>0.8851$ ). In addition, the values of theoretical biosorption capacities were in agreement with the experimental values; nevertheless, further investigation is needed to clarify the kinetics of such systems.

When comparing single-metal solutions to multi-metal solutions, the removal efficiency for $\mathrm{Cu}^{2+}$ in multi-metal solution decreased by only 5-7\%. On the other hand, a considerably greater decrease was observed in the cases of $\mathrm{Cd}^{2+}$ and $\mathrm{Ni}^{2+}$ biosorptions, whereas the removal efficiencies for these two metals could decrease by as much as $30 \%$. These results showed that multi-metal biosorptions of $\mathrm{Cu}^{2+}, \mathrm{Ni}^{2+}$ and $\mathrm{Cd}^{2+}$ ions by alginate-immobilised $C$. sorokiniana are much more complex than biosorptions of bi- or single-metal systems. Although biosorption at higher initial concentrations is possible and sufficient effectiveness could be obtained, the biosorption operation at such concentrations, especially in bi-metal and multi-metal systems, could lead to a toxicity effect of these metals on the cells of $C$. sorokiniana.

From the collated results, it was also noticed that differences in the removal efficiencies (or biosorption capacities) between single and bi-metal systems are smaller than the differences between single-metal and multi-metal 


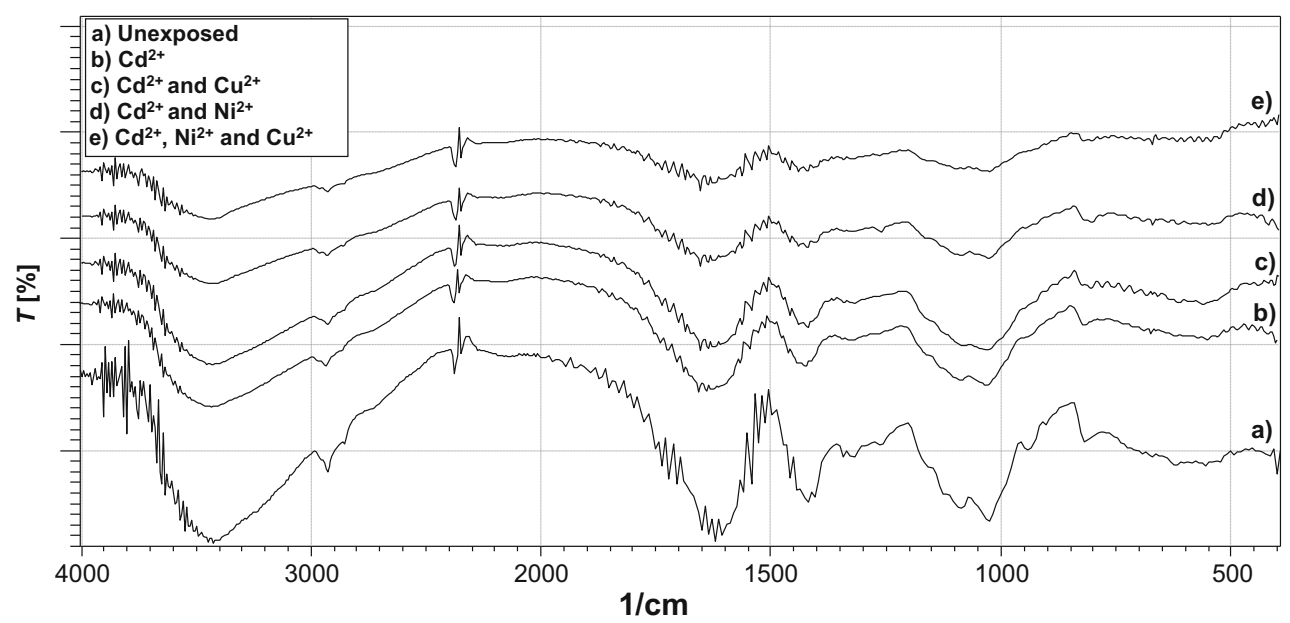

Fig. 6 The FTIR spectra of alginate-immobilised C. sorokiniana beads exposed to solutions containing different metals and combinations (be) in comparison to the spectrum of the unexposed algal beads (a)

or bi-metal and multi-metal systems. There were some exceptions in the case of $\mathrm{Cu}^{2+}$ sorption; however, as in the bi-metal and multi-metal systems, similar or even higher capacities were detected than in the single-metal solution. Otherwise, the capacities of both $\mathrm{Cd}^{2+}$ and $\mathrm{Ni}^{2+}$ were negatively affected by $\mathrm{Cu}^{2+}$ ions, which means that in the multi-metal system, alginate-immobilised algae had a higher affinity for $\mathrm{Cu}^{2+}$ than for the other two metals. The adsorption experiments on a similar multi-metal system of $\mathrm{Cu}^{2+}, \mathrm{Zn}^{2+}$ and $\mathrm{Ni}^{2+}$ performed with alginate-immobilised Scenedesmus quadricauda also showed higher selectivity of that biosorbent for $\mathrm{Cu}^{2+}$ ions than for the other two metals (Bayramoğlu and Yakup Arıca 2009). Otherwise, the preference for the metals tested was the same as already mentioned in bi-metal systems.

Since Fourier transform infrared spectroscopy (FTIR) has been successfully implemented in various studies on surface chemical characteristics of adsorbents (D'Souza et al. 2008; Saleh 2011; Saleh 2015a, b; Samuel et al. 2013), the FTIR spectra of the biosorbents used in this study were recorded before and after exposure to metals. The FTIR spectra of alginate-immobilised $C$. sorokiniana beads exposed to different combinations of $\mathrm{Cu}^{2+}, \mathrm{Ni}^{2+}$ and $\mathrm{Cd}^{2+}$ ions (at initial metal concentrations of $30 \mathrm{mg} / \mathrm{L}$ ) compared to that of unexposed algal beads are shown in Fig. 6. The surface chemical characteristics, i.e. functional groups of the alginate-immobilised algal beads unexposed to metals (Fig. 6, sample a), were examined precisely in our previous study (Petrovič and Simonič 2015), whereby the strongest absorption peak found at $3402 \mathrm{~cm}^{-1}$ corresponded to the $-\mathrm{OH}$ stretching of hydroxyls, indicating the presence of these groups on the biosorbent. The region $3600-3300 \mathrm{~cm}^{-1}$ showed, next to the $\mathrm{O}-\mathrm{H}$ vibrations, the characteristic bands for $\mathrm{N}-\mathrm{H}$ stretching vibrations, which can be attributed to algal biomass. Besides this, several other functional groups were identified, such as $\mathrm{C}-\mathrm{H}$ bending of the aliphatic functional group (2924-2854 $\mathrm{cm}^{-1}$ ) and C-C stretching vibrations of the aromatic ring $\left(1419 \mathrm{~cm}^{-1}\right)$, whilst $\mathrm{C}-\mathrm{N}$ stretching of aromatics and $\mathrm{C}-\mathrm{O}$ stretching of alcohols and carboxylic acids were found in the region of $1265-1319 \mathrm{~cm}^{-1}$. In the region between 1800 and $1500 \mathrm{~cm}^{-1}$, the characteristic bands for proteins can be seen, more specifically $\mathrm{C}=\mathrm{O}$ stretching vibrations of peptide bonds typical of amide-I bands and $\mathrm{N}-\mathrm{H}$ bending vibrations characteristic of amide-II bands. The strongest peak in this area was found at $1604 \mathrm{~cm}^{-1}$, reflecting the amines and amides of algal biomass. On the other hand, the $\mathrm{C}-\mathrm{O}$ stretching vibrations of alcohols, carboxylic acids and carbohydrate of polysaccharides of both algal biomass and alginate were noticed in the region between 1026 and $1087 \mathrm{~cm}^{-1}$ (see Fig. 6).

A comparison of the spectra of unexposed biosorbent and metal-exposed biosorbent shows that the strongest peaks were observed in the case of unexposed algal beads, indicating that the biosorbent consisted of a large number of functional groups that are available for the binding of metals. After biosorption of metal (for example $\mathrm{Cd}^{2+}$ ions, Fig. 6, sample b), the peaks showed a shift to lower wavenumber, as a result of the occupying of free functional groups by sorbate. A similar decrease in the intensity of absorption bands in the region $1800-800 \mathrm{~cm}^{-1}$ (which is specific for proteins and carbohydrates) has been already reported for marine brown algae treated by $\mathrm{Cd}^{2+}$ ions (D'Souza et al. 2008). However, with increasing numbers of sorbates (i.e. metals) in the solution, the difference was even more striking and the peaks were even weaker (samples c and d). The weakest peaks were found in the sample of algal beads exposed to a combination of $\mathrm{Cu}^{2+}, \mathrm{Ni}^{2+}$ and $\mathrm{Cd}^{2+}$ ions in the 
solution (sample e). This can be explained by the fact that with increasing the number of metals, more and more functional groups are occupied; therefore, fewer free sites are available for the biosorptions of metals and consequently the peaks were lower. Thus, the comparison of FTIR spectra of unexposed and metal-exposed biosorbent provides clear evidence that the highest decrease in the bands' intensities were noticed in the cases of $-\mathrm{OH}$ stretching of hydroxyls, C-O stretching of alcohols, carboxylic acids and carbohydrate, and the $\mathrm{N}-\mathrm{H}$ bending of amines and amides, indicating that these functional groups play a significant role in binding the tested metals. Hydroxyl groups present in polysaccharides have a high affinity for divalent cations, so they can significantly contribute to biosorption of metals (D'Souza et al. 2008).

\section{Conclusion}

This study demonstrated that $C$. sorokiniana cells immobilised in Ca-alginate can be effective biosorbents for $\mathrm{Cu}^{2+}, \mathrm{Ni}^{2+}$ and $\mathrm{Cd}^{2+}$ removal, but in the case of $\mathrm{Ni}^{2+}$, lower biosorption efficiencies than for the other two metals can be expected. The biosorptions of the metals were strongly affected by the initial metal ion concentrations and initial $\mathrm{pH}$. The highest removal yields for $\mathrm{Cu}^{2+}, \mathrm{Ni}^{2+}$ and $\mathrm{Cd}^{2+}$ ions were 97,51 and $74 \%$, respectively.

The Langmuir, Freundlich and Redlich-Peterson model fit closely the equilibrium data obtained during these experiments, demonstrating that both monolayer biosorption and heterogeneous surface biosorption occur during biosorption by immobilised algae. At an initial metal concentration of $25 \mathrm{mg} / \mathrm{L}$, alginate-immobilised $C$. sorokiniana cells could be used for 5 or even more successive biosorption-desorption cycles and still sufficiently remove metal ions. However, at the highest initial metal concentrations tested, all three heavy metals affected algal growth. The biosorption capacities and separation factors of $\mathrm{Cu}^{2+}, \mathrm{Ni}^{2+}$ and $\mathrm{Cd}^{2+}$ ions showed that biosorptions follow the order of $\mathrm{Cu}^{2+}>\mathrm{Cd}^{2+}>\mathrm{Ni}^{2+}$, indicating selective biosorption. The biosorption capacities for all metals were the highest in the single-metal systems, and they decreased with the number of co-ions in the solution. Although the presence of other metals in the solution negatively affects biosorption uptake, alginate-immobilised C. sorokiniana could still sufficiently remove heavy metals from drinking water samples containing total metal concentrations of up to $100 \mathrm{mg} / \mathrm{L}$.

Acknowledgments The authors would like to acknowledge the Slovenian Research Agency (Javna Agencija za Raziskovalno Dejavnost RS) for their financial support (Project No. 1000-11310131).

\section{References}

Abdel-Ghani NT, El-Chaghaby GA (2014) Biosorption for metal ions removal from aqueous solutions: a review of recent studies. Int $\mathbf{J}$ Latest Res Sci Technol 3:24-42

Akhtar N, Saeed A, Iqbal M (2003) Chlorella sorokiniana immobilized on the biomatrix of vegetable sponge of Luffa cylindrica: a new system to remove cadmium from contaminated aqueous medium. Bioresour Technol 88:163-165. doi:10.1016/S09608524(02)00289-4

Akhtar N, Iqbal J, Iqbal M (2004) Removal and recovery of nickel(II) from aqueous solution by loofa sponge-immobilized biomass of Chlorella sorokiniana: characterization studies. J Hazard Mater 108:85-94. doi:10.1016/j.jhazmat.2004.01.002

Akhtar N, Iqbal M, Zafar SI, Iqbal J (2008) Biosorption characteristics of unicellular green alga Chlorella sorokiniana immobilized in loofa sponge for removal of $\mathrm{Cr}(\mathrm{III})$. J Environ Sci 20:231-239. doi:10.1016/S1001-0742(08)60036-4

Aksu Z (2001) Equilibrium and kinetic modelling of cadmium(II) biosorption by $\mathrm{C}$. vulgaris in a batch system: effect of temperature. Sep Purif Technol 21:285-294. doi:10.1016/ S1383-5866(00)00212-4

Aksu Z (2002) Determination of the equilibrium, kinetic and thermodynamic parameters of the batch biosorption of nickel(II) ions onto Chlorella vulgaris. Process Biochem 38:89-99. doi:10. 1016/S0032-9592(02)00051-1

Aksu Z, Dönmez G (2006) Binary biosorption of cadmium(II) and nickel(II) onto dried Chlorella vulgaris: co-ion effect on monocomponent isotherm parameters. Process Biochem 41:860-868. doi:10.1016/j.procbio.2005.10.025

Al-Rub FAA, El-Naas MH, Benyahia F, Ashour I (2004) Biosorption of nickel on blank alginate beads, free and immobilized algal cells. Process Biochem 39:1767-1773. doi:10.1016/j.procbio. 2003.08.002

Al-Rub FAA, El-Naas MH, Ashour I, Al-Marzouqi M (2006) Biosorption of copper on Chlorella vulgaris from single, binary and ternary metal aqueous solutions. Process Biochem 41:457-464. doi:10.1016/j.procbio.2005.07.018

Bayramoğlu G, Yakup Arıca M (2009) Construction a hybrid biosorbent using Scenedesmus quadricauda and Ca-alginate for biosorption of $\mathrm{Cu}(\mathrm{II}), \mathrm{Zn}(\mathrm{II})$ and $\mathrm{Ni}(\mathrm{II})$ : kinetics and equilibrium studies. Bioresour Technol 100:186-193. doi:10.1016/j.biortech. 2008.05.050

Bischoff H, Bold HC (2003) Psychological studies IV. Some soil algae from enchanted rock and related algal species, vol 6318. University Texas Publications, Austin

Blanes P et al (2011) Biosorption of trivalent chromium from aqueous solution by red seaweed Polysiphonia nigrescens. J Water Resource Prot 3:832-843

Bulgariu D, Bulgariu L (2012) Equilibrium and kinetics studies of heavy metal ions biosorption on green algae waste biomass. Bioresour Technol 103:489-493. doi:10.1016/j.biortech.2011. 10.016

Carfagna S, Lanza N, Salbitani G, Basile A, Sorbo S, Vona V (2013) Physiological and morphological responses of Lead or Cadmium exposed Chlorella sorokiniana 211-8 K (Chlorophyceae). SpringerPlus 2:147. doi:10.1186/2193-1801-2-147

Chong AMY, Wong YS, Tam NFY (2000) Performance of different microalgal species in removing nickel and zinc from industrial wastewater. Chemosphere 41:251-257. doi:10.1016/S00456535(99)00418-X

D'Souza L, Devi P, Divya Shridhar MP, Naik CG (2008) Use of Fourier transform infrared (FTIR) spectroscopy to study cadmium-induced changes in Padina Tetrastromatica (Hauck). Anal Chem Insights 3:135-143 
de-Bashan LE, Bashan Y (2010) Immobilized microalgae for removing pollutants: review of practical aspects. Bioresour Technol 101:1611-1627. doi:10.1016/j.biortech.2009.09.043

de-Bashan LE, Trejo A, Huss VAR, Hernandez J-P, Bashan Y (2008) Chlorella sorokiniana UTEX 2805, a heat and intense, sunlighttolerant microalga with potential for removing ammonium from wastewater. Bioresour Technol 99:4980-4989. doi:10.1016/j. biortech.2007.09.065

Dubinin MM (1960) The potential theory of adsorption of gases and vapors for adsorbents with energetically non-uniform surface. Chem Rev 60:235-266

Flouty R, Estephane G (2012) Bioaccumulation and biosorption of copper and lead by a unicellular algae Chlamydomonas reinhardtii in single and binary metal systems: a comparative study. J Environ Manage 111:106-114. doi:10.1016/j.jenvman. 2012.06.042

Flouty R, Khalaf G (2015) Role of $\mathrm{Cu}$ and $\mathrm{pb}$ on Ni bioaccumulation by Chlamydomonas reinhardtii: validation of the biotic ligand model in binary metal mixtures. Ecotox Environ Safe 113:79-86. doi:10.1016/j.ecoenv.2014.11.022

Foo KY, Hameed BH (2010) Insights into the modeling of adsorption isotherm systems. Chem Eng J 156:2-10. doi:10.1016/j.cej.2009. 09.013

Freundlich H (1926) Colloid and capillary chemistry. Methuen, London

Gupta VK, Saleh TA (2013) Sorption of pollutants by porous carbon, carbon nanotubes and fullerene: an overview. Environ Sci Pollut Res 20:2828-2843. doi:10.1007/s11356-013-1524-1

Gupta VK, Agarwal S, Saleh TA (2011a) Chromium removal by combining the magnetic properties of iron oxide with adsorption properties of carbon nanotubes. Water Res 45:2207-2212. doi:10.1016/j.watres.2011.01.012

Gupta VK, Agarwal S, Saleh TA (2011b) Synthesis and characterization of alumina-coated carbon nanotubes and their application for lead removal. J Hazard Mater 185:17-23. doi:10.1016/j. jhazmat.2010.08.053

Gupta VK, Jain R, Saleh TA, Nayak A, Malathi S, Agarwal S (2011c) Equilibrium and thermodynamic studies on the removal and recovery of Safranine-T dye from industrial effluents. Separ Sci Technol 46:839-846. doi:10.1080/01496395.2010.535591

Gupta VK, Ali I, Saleh TA, Nayak A, Agarwal S (2012a) Chemical treatment technologies for waste-water recycling-an overview. RSC Adv 2:6380-6388. doi:10.1039/c2ra20340e

Gupta VK, Jain R, Mittal A, Saleh TA, Nayak A, Agarwal S, Sikarwar S (2012b) Photo-catalytic degradation of toxic dye amaranth on $\mathrm{TiO} 2 / \mathrm{UV}$ in aqueous suspensions. Mater Sci Eng C 32:12-17. doi:10.1016/j.msec.2011.08.018

Gupta VK, Kumar R, Nayak A, Saleh TA, Barakat MA (2013) Adsorptive removal of dyes from aqueous solution onto carbon nanotubes: a review. Adv Colloid Interface Sci 193-194:24-34. doi:10.1016/j.cis.2013.03.003

Hall KR, Eagleton LC, Acrivos A, Vermeulen T (1966) Pore-and solid diffusion kinetics in fixed-bed adsorption under constantpattern conditions. Ind Eng Chem Fund 5:212-223

Ho YS, McKay G (1998) Kinetic models for the sorption of dye from aqueous solution by wood. Process Saf Environ 76:183-191

Ho YS, McKay G (1999) Pseudo-second order model for sorption processes. Process Biochem 34:451-465

Ihsanullah et al (2015) Adsorptive removal of cadmium(II) ions from liquid phase using acid modified carbon-based adsorbents. J Mol Liq 204:255-263. doi:10.1016/j.molliq.2015.01.033

Kaewsarn P, Yu Q (2001) Cadmium(II) removal from aqueous solutions by pre-treated biomass of marine alga Padina sp. Environ Pollut 112:209-213. doi:10.1016/S0269-7491(00) 00114-7
Kim S, J-e Park, Cho Y-B, Hwang S-J (2013) Growth rate, organic carbon and nutrient removal rates of Chlorella sorokiniana in autotrophic, heterotrophic and mixotrophic conditions. Bioresour Technol 144:8-13. doi:10.1016/j. biortech.2013.06.068

Kumar K, Das D (2012) Growth characteristics of Chlorella sorokiniana in airlift and bubble column photobioreactors. Bioresour Technol 116:307-313. doi:10.1016/j.biortech.2012. 03.074

Lagergren S (1898) About the theory of so-called adsorption of soluble substances. Kungliga Svenska Vetenskapsakademiens, Handlingar 24:1-39

Langmuir I (1916) The constitution and fundamental properties of solids and liquids. J Am Chem Soc 38:2221-2295

Lizzul AM, Hellier P, Purton S, Baganz F, Ladommatos N, Campos L (2014) Combined remediation and lipid production using Chlorella sorokiniana grown on wastewater and exhaust gases. Bioresour Technol 151:12-18. doi:10.1016/j.biortech.2013.10. 040

Mane PC, Bhosle AB (2011) Bioremoval of some metals by living algae Spirogyra sp. and Spirullina sp. from aqueous solution. Int. J Environ Res 6(2):571-576

Mehta SK, Gaur JP (2001) Removal of $\mathrm{Ni}$ and $\mathrm{Cu}$ from single and binary metalsolutions by free and immobilized Chlorella vulgaris. Eur J Protistol 37:261-271. doi:10.1078/0932-473900813

Monteiro C, Castro PL, Xavier Malcata F (2011) Biosorption of zinc ions from aqueous solution by the microalga Scenedesmus obliquus. Environ Chem Lett 9:169-176. doi:10.1007/s10311009-0258-2

Onyancha D, Mavura W, Ngila JC, Ongoma P, Chacha J (2008) Studies of chromium removal from tannery wastewaters by algae biosorbents, Spirogyra condensata and Rhizoclonium hieroglyphicum. J Hazard Mater 158:605-614. doi:10.1016/j.jhazmat. 2008.02.043

Pawar SN, Edgar KJ (2012) Alginate derivatization: a review of chemistry, properties and applications. Biomaterials 33:3279-3305. doi:10.1016/j.biomaterials.2012.01.007

Petrovič A, Simonič M (2015) The effect of carbon source on nitrate and ammonium removal from drinking water by immobilised Chlorella sorokiniana. Int J Environ Sci Technol 12:3175-3188. doi:10.1007/s13762-014-0747-0

Riaño B, Hernández D, García-González MC (2012) Microalgalbased systems for wastewater treatment: effect of applied organic and nutrient loading rate on biomass composition. Ecol Eng 49:112-117. doi:10.1016/j.ecoleng.2012.08.021

Rodrigues MS, Ferreira LS, Carvalho JCMd, Lodi A, Finocchio E, Converti A (2012) Metal biosorption onto dry biomass of Arthrospira (Spirulina) platensis and Chlorella vulgaris: multimetal systems. J Hazard Mater 217-218:246-255. doi:10.1016/j. jhazmat.2012.03.022

Romera E, González F, Ballester A, Blázquez ML, Muñoz JA (2007) Comparative study of biosorption of heavy metals using different types of algae. Bioresour Technol 98:3344-3353. doi:10.1016/j. biortech.2006.09.026

Saleh TA (2011) The influence of treatment temperature on the acidity of MWCNT oxidized by HNO3 or a mixture of HNO3/ H2SO4. Appl Surf Sci 257:7746-7751. doi:10.1016/j.apsusc. 2011.04.020

Saleh TA (2015a) Isotherm, kinetic, and thermodynamic studies on $\mathrm{Hg}(\mathrm{II})$ adsorption from aqueous solution by silica- multiwall carbon nanotubes. Environ Sci Pollut Res 22:16721-16731. doi:10.1007/s11356-015-4866-z

Saleh TA (2015b) Nanocomposite of carbon nanotubes/silica nanoparticles and their use for adsorption of $\mathrm{Pb}(\mathrm{II})$ : from surface 
properties to sorption mechanism. Desalin Water Treat 57:10730-10744. doi:10.1080/19443994.2015.1036784

Saleh TA, Gupta VK (2011) Functionalization of tungsten oxide into MWCNT and its application for sunlight-induced degradation of rhodamine B. J Colloid Interface Sci 362:337-344. doi:10.1016/ j.jcis.2011.06.081

Saleh TA, Gupta VK (2012a) Photo-catalyzed degradation of hazardous dye methyl orange by use of a composite catalyst consisting of multi-walled carbon nanotubes and titanium dioxide. J Colloid Interface Sci 371:101-106. doi:10.1016/j. jcis.2011.12.038

Saleh TA, Gupta VK (2012b) Synthesis and characterization of alumina nano-particles polyamide membrane with enhanced flux rejection performance. Sep Purif Technol 89:245-251. doi:10. 1016/j.seppur.2012.01.039

Saleh TA, Gupta VK (2014) Processing methods, characteristics and adsorption behavior of tire derived carbons: a review. Adv Colloid Interface Sci 211:93-101. doi:10.1016/j.cis.2014.06.006

Saleh TA, Agarwal S, Gupta VK (2011) Synthesis of MWCNT/MnO2 and their application for simultaneous oxidation of arsenite and sorption of arsenate. Appl Catal B-Environ 106:46-53. doi:10. 1016/j.apcatb.2011.05.003
Samuel J, Pulimi M, Paul ML, Maurya A, Chandrasekaran N, Mukherjee A (2013) Batch and continuous flow studies of adsorptive removal of $\mathrm{Cr}(\mathrm{VI})$ by adapted bacterial consortia immobilized in alginate beads. Bioresour Technol 128:423-430. doi:10.1016/j.biortech.2012.10.116

Sarı A, Tuzen M (2009) Equilibrium, thermodynamic and kinetic studies on aluminum biosorption from aqueous solution by brown algae (Padina pavonica) biomass. J Hazard Mater 171:973-979. doi:10.1016/j.jhazmat.2009.06.101

Wan Maznah WO, Al-Fawwaz AT, Surif M (2012) Biosorption of copper and zinc by immobilised and free algal biomass, and the effects of metal biosorption on the growth and cellular structure of Chlorella sp. and Chlamydomonas sp. isolated from rivers in Penang Malaysia. J Environ Sci 24:1386-1393. doi:10.1016/ S1001-0742(11)60931-5

Yoshida N, Ikeda R, Okuno T (2006) Identification and characterization of heavy metal-resistant unicellular alga isolated from soil and its potential for phytoremediation. Bioresour Technol 97:1843-1849. doi:10.1016/j.biortech.2005.08.021 